\title{
Thermal conductivity of supraglacial volcanic deposits in Iceland
}

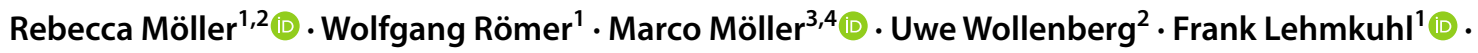 \\ Christoph Schneider ${ }^{4}$. Peter A. Kukla ${ }^{2}$ (I)
}

Received: 28 January 2019 / Accepted: 8 January 2020 / Published online: 18 February 2020

(c) The Author(s) 2020

\begin{abstract}
Supraglacial deposits of tephra or volcaniclastics have the potential to cause significant anomalies of glacier ablation and runoff. The intensity of these anomalies is governed by the thermal resistivity of the covering layer and hence the thermal conductivity of the deposited grains. This study concentrates on causal and quantitative relationships between density, geochemical composition and thermal conductivity of volcanic materials based on the analysis of 43 samples from locations across Iceland. Thermal conductivity is primarily influenced by density, whereas geochemical composition has been proved to be of subsidiary importance. Four different multiple regression models were calibrated that calculate the grain thermal conductivity of a volcanic material based on rock properties and geochemical composition. In a subsequent step, the bulk thermal conductivity of the respective deposit is calculated as a function of porosity and degree of water saturation. Examples using volcanic material from the Eyjafjallajökull 2010 and Grímsvötn 2011 eruptions confirm that the presented calculation scheme can be executed using only limited geochemical data as input. This facilitates an easy application of the modeling scheme immediately after a volcanic eruption.
\end{abstract}

Keywords Volcanic tephra $\cdot$ Thermal conductivity $\cdot$ Major element oxides $\cdot$ Iceland $\cdot$ Modeling

\section{Introduction}

Volcanic tephra and volcaniclastics can be dispersed over vast areas around a source vent by fallout following ejection through an explosive eruption. The generated layers of volcanic material are characterized by high spatial heterogeneity with thicknesses ranging over several orders of magnitude (Brown et al. 2012). The high dispersion of the volcanic materials is often associated with a considerable influence

Electronic supplementary material The online version of this article (https://doi.org/10.1007/s00531-020-01820-0) contains supplementary material, which is available to authorized users.

Rebecca Möller

rebecca.moeller@geo.rwth-aachen.de

1 Department of Geography, RWTH Aachen University, Aachen, Germany

2 Geological Institute, Energy and Minerals Resources Group, RWTH Aachen University, Aachen, Germany

3 Institute of Geography, University of Bremen, Bremen, Germany

4 Geography Department, Humboldt-Universität zu Berlin, Berlin, Germany on humans and ecosystems (Machida 2002). Among the abiotic components of the ecosystems, especially permafrost features and glaciers are affected by deposition of volcanic materials (Kellerer-Pirklbauer et al. 2007; Kirkbride and Dugmore 2003).

In the cryosphere, influences related to alterations of the surface energy and mass balance of either the frozen ground, the snow or the glacier ice are crucial (Dragosics et al. 2016; Möller et al. 2018). Two counteracting effects govern the strength of these alterations (Möller et al. 2016). The first is the albedo effect, which enhances ablation due to a darkening of the glacier surface and the related increase of absorbed radiation energy. It increases with thickness of the deposited volcanic material up to full coverage of the glacier surface and remains constant afterwards. The second is the thermal resistance effect, which reduces ablation due to the decrease of heat conducted from the air to the glacier surface. Thermal resistance increases with deposition thickness and it can be quantified either by empirical measurements or by physics-based considerations of the thermal properties of the deposit (Möller et al. 2016; Nicholson and Benn 2013). While deposition thickness is process-related, the thermal properties and, in particular, thermal conductivity 
are strongly related to the petrographical characteristics of the volcanic material and to the water content of the deposit (Clauser and Huenges 1995; Kuznetsova 2017). Relations between thermal conductivity of rocks and their petrographical characteristics are well documented and calculation methods have long been known (e.g., Horai and Baldridge 1972; Corson 1974; García et al. 1989).

In Iceland, glaciers cover an area of $\sim 11,100 \mathrm{~km}^{2}$ (Fig. 1) and thus about $11 \%$ of the island (Björnsson and Pálsson 2008). Icelandic volcanoes have experienced a considerable number of eruptions in historical times, several of which were phreatomagmatic and thus of the explosive type (Thordarson and Larsen 2007). Significant amounts of proximal tephra fallout were documented for the eruptions of Hekla, in 1991 (Gudnason et al. 2017), Grímsvötn, in 2004 (Jude-Eton et al. 2012), and Eyjafjallajökull, in 2010 (Gudmundsson et al. 2012). However, volcanic deposits found on Iceland are not always original in situ tephra deposits, but may also be secondary deposits of volcaniclastics after aeolian transport away from their original deposition site (Arnalds et al. 2016; Liu et al. 2014). Frequent strong winds promote wind erosion, especially of fine-grained volcanic ashes (Arnalds et al. 2013; Dagsson-Waldhauserova et al. 2014). Similar to tephra fallout (Möller et al. 2014, 2019), the resulting dust storms have the potential to deposit considerable amounts of petrographically and geochemically different volcanic material on surrounding glaciers (Wittmann et al. 2017).

Based on a collection of 43 samples of volcanic materials from various locations on Iceland, we here investigate the hypothesis that the varying petrographical characteristics of the volcanic materials cause substantially different thermal properties among the associated supraglacial deposits. These in turn may influence glacier ablation and potentially result in altered timings and magnitudes of peak runoff which may exert a significant geohazard impact.

We analyze to which extent the variability of grain thermal conductivity is related to petrographical characteristics, in particular grain density and geochemical composition. We investigate whether this relation can be described by statistical relationships and evaluate the possibility of inferring the grain thermal conductivity of the volcanic materials from their grain density and/or geochemical composition by means of regression modeling. We further present constraints for the bulk thermal conductivity of a deposit of volcanic materials considering its pore space and water content in addition to the grain thermal conductivity.

Finally, we test to which extent it is feasible to estimate grain and bulk thermal conductivity of a volcanic deposit from literature-derived geochemical compositions only.

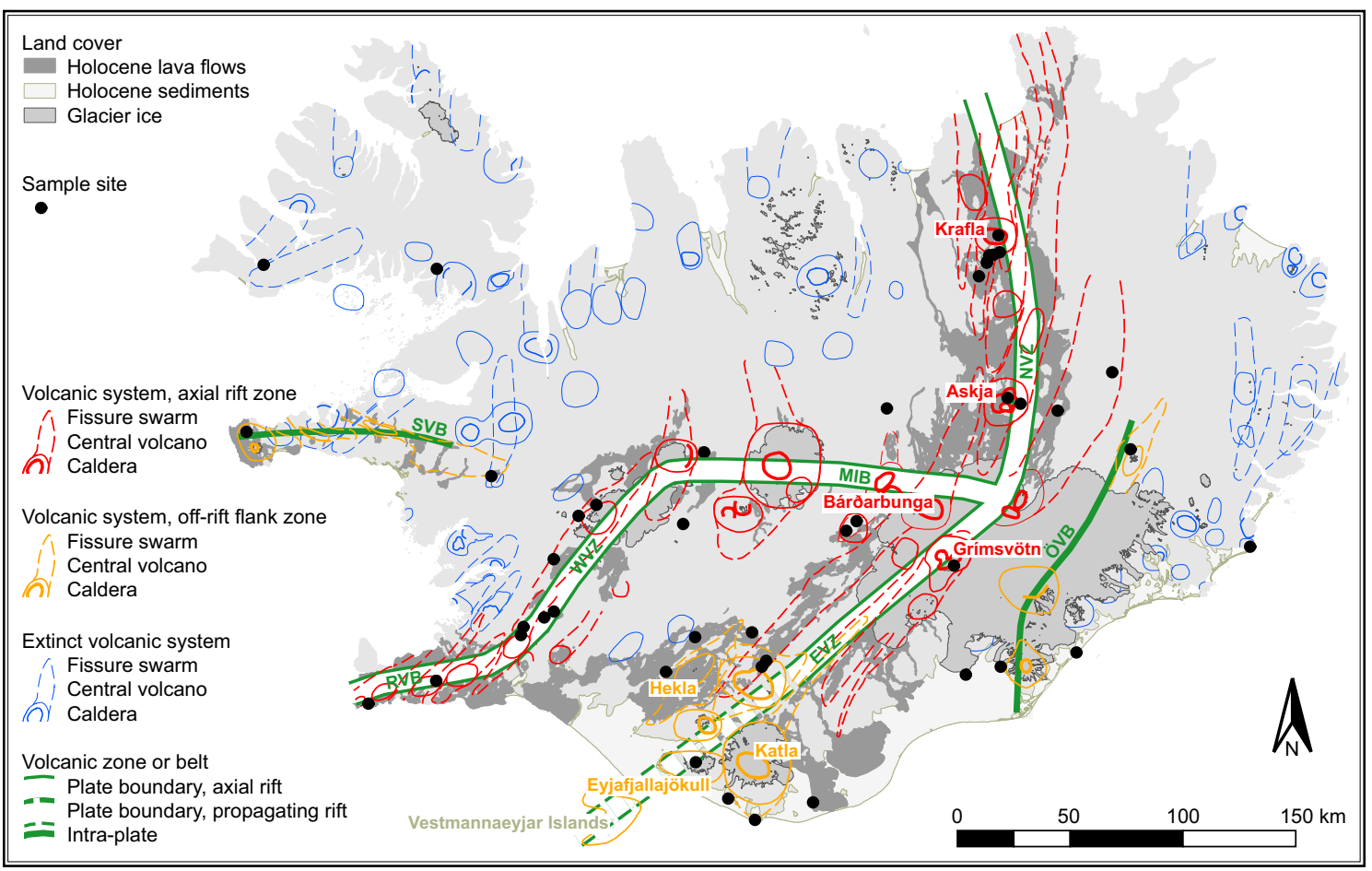

Fig. 1 Tectonic-volcanic systems across Iceland, with distribution of Holocene lava deposits, sediments and glacier area. Sample locations are marked by black dots. For sample IDs see Fig. 2. Geological information on the map is adapted from Jóhannesson and Sæmunds- son (2009). The western, eastern and northern volcanic zones (WVZ, EVZ and NVZ) are shown along with the mid-Iceland belt (MIB). The Reykjanes (RVB), Snæfellsness (SVB) and Öræfi volcanic belts (ÖVB) are shown in addition 
Doing so would facilitate estimations immediately after volcanic eruptions when only the characteristic geochemical fingerprints of the respective source volcanos are known. Such an approach might have the potential to be further developed into a useful and fast-response tool for geohazard assessment.

\section{Study area and sampling sites}

Volcanic structures on Iceland are organized into zones, which mainly follow the plate boundaries associated with the continuation of the mid-ocean ridge across the island (Sæmundsson 1979; Thordarson and Larsen 2007). From the south, there are the Reykjanes Volcanic Belt (RVB), the Western Volcanic Zone (WVZ), the Mid-Iceland Belt (MIB) and the Northern Volcanic Zone (NVZ) (Fig. 1). The Eastern Volcanic Zone (EVZ) has developed in the off-rift flank zone since the late Pliocene through propagating axial rifting towards the south and is thought to continue the same in the future (Gudmundsson 1995). Apart from these plate boundary-oriented volcanic zones, two active intraplate zones also exist, the Snæfellsness Volcanic Belt (SVB) and the Öræfi Volcanic Belt (ÖVB).

Along the main axial rift zone, i.e., from RVB to NVZ, volcanic activity is dominated by tholeiitic magmatism while across the off-rift flank zones transitional alkaline or even alkaline magmatism dominates (Jakobsson et al. 2008; Sigmarsson and Steinthórsson 2007). The northern part of the off-rift EVZ is still dominated by tholeiitic magmatism, before it changes into a transitional alkaline magmatism in its central parts and even further into a mildly alkaline magmatism on the Vestmannaeyjar islands (Jakobsson 1979). Magmatism in the ÖVB is closely related to the central parts of the EVZ and is likewise transitional alkaline. In the SVB, in contrast, magmatism is mildly alkaline and thus similar to that on the Vestmannaeyjar islands (Jakobsson et al. 2008).

Active volcanism in Iceland is confined to about thirty active central volcano systems (Fig. 1), characterized by both effusive and explosive eruptions with lava and tephra compositions ranging from basaltic to rhyolitic (Thordarson and Höskuldsson 2008; Thordarson and Larsen 2007). Due to the presence of glacier ice over many of the volcanic vents, even mafic magmas are mostly erupted explosively in a phreatomagmatic style (Jakobsson and Gudmundsson 2008; Larsen and Eiríksson 2007). Only 22\% of the historic mafic eruptions were effusive (Thordarson and Höskuldsson 2008). Several volcano systems are known to have characteristic geochemical compositions, i.e., major element oxide ratios (Gudmundsdóttir et al. 2016; Larsen et al. 1998). However, these ratios are not always unambiguous as the affinity of neighboring systems can be large enough to induce at least partly overlapping fingerprints (Neave et al. 2015; Óladóttir et al. 2008).

Volcanic activity in historical times was dominated by four distinct central volcanos all located in the EVZ. About $80 \%$ of the total volume of erupted magma can be assigned to the Katla (28\%), Grímsvötn (25\%), Hekla (15\%) and Veiðivötn-Bárðarbunga (12\%) volcano systems (Thordarson and Larsen 2007). Among them, Grímsvötn experienced by far the highest number of eruptions including the most recent explosive one in 2011 (Óladóttir et al. 2011; Stevenson et al. 2013). Among the historic eruptions, $88 \%$ of the explosive and $45 \%$ of the effusive events occurred in this zone, producing $93 \%$ of all erupted tephra and $44 \%$ of all erupted lava (Thordarson and Höskuldsson 2008).

Our sampling strategy accounts for the variability of volcanic deposits across Iceland. The locations of the sampling points (Figs. 1,2) were primarily chosen to mirror the major central volcanoes along the volcanic zones with special emphasis on RVB, WVZ, NVZ and EVZ where about 98\% of all historic volcanic activity occurred (Thordarson and Höskuldsson 2008). Field sampling covered most of the rock types present on Iceland, despite the broad prevalence of basaltic tephra and lava (Sigmarsson and Steinthórsson 2007).

In the NVZ, we particularly concentrated on locations close to two major central volcanoes, Askja and Krafla. In the EVZ, we concentrated on locations representing two major central volcanoes, i.e., Hekla and Katla. For the latter, sampling locations in the extensive sandur plains of the Myrdalsjökull ice cap were chosen, thus exhibiting fluvial relocation of the original tephra deposits. Moreover, at Eyjafjallajökull and Grímsvötn volcanoes, samples were taken inside the summit caldera and at the caldera rim, respectively, to acquire pristine tephra from the two most recent eruptions.

In the two intraplate volcanic zones ÖVB and SVB, samples were collected to represent the major central volcanos, i.e., Snæfell (ÖVB) and Snæfellsjökull (SVB). In addition, sampling included a couple of extinct volcanoes in the southeast and northwest of the island.

To account for the widespread distribution, the high variability and petrographic diversity of volcanic deposits across Iceland, our sampling encompassed original tephra deposits as well as volcaniclastic sediments. No samples were taken from notably weathered or silt-covered sediments to keep the chemical composition of the volcaniclastics as original as possible. Nevertheless, samples might have been altered by weathering or mixing with ex situ materials.

Three different types of sampling sites have to be distinguished: first, subsurface materials, which crop out in natural scarps; second, surface materials from vegetation- and soil-free sandy plains; third, the calderas of Eyjafjallajökull and Grímsvötn wherein it was necessary to sample surface 

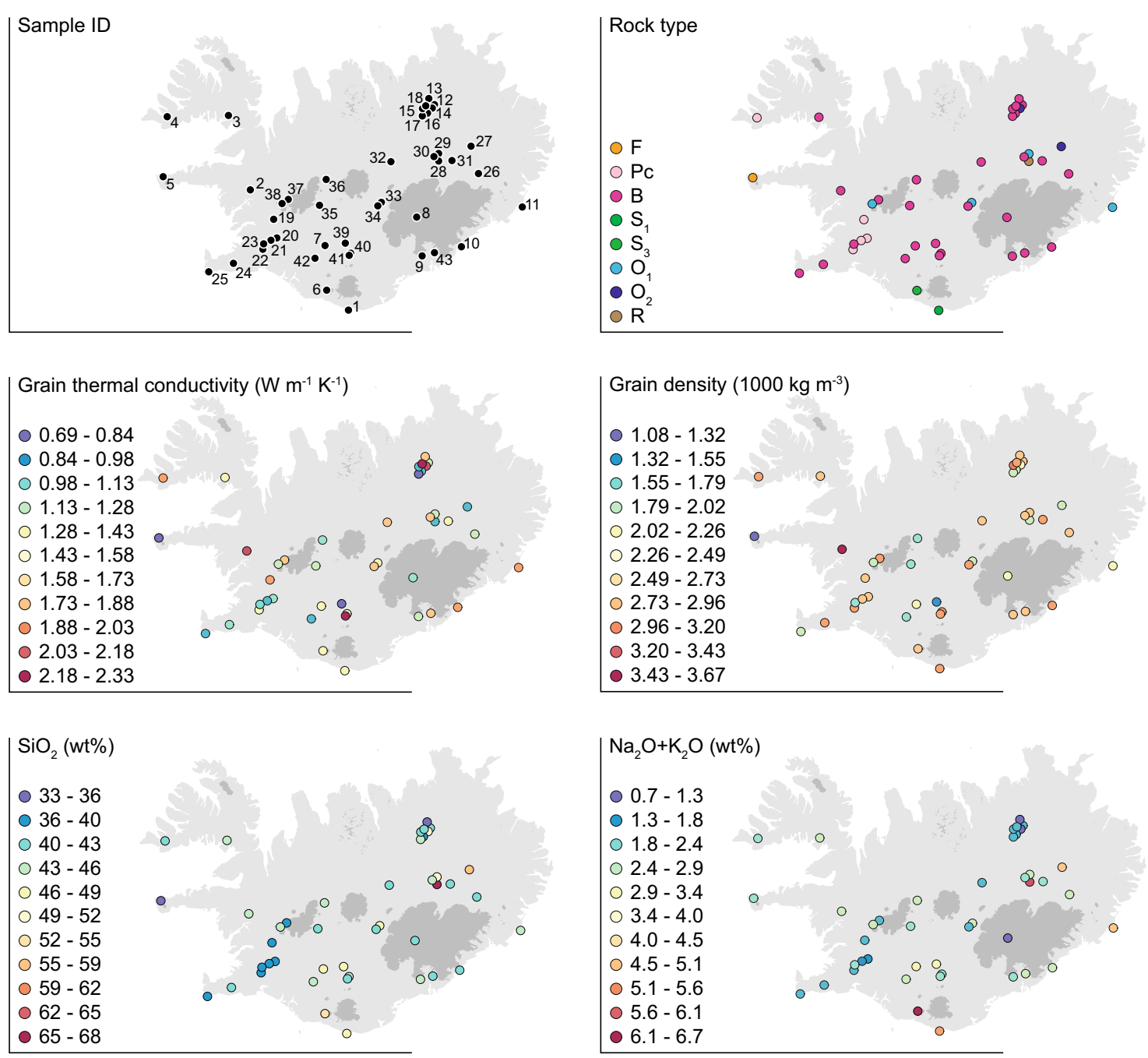

Fig. 2 Spatial overview of sampling sites. For each site, the sample ID is shown along with the rock type. Assignments of the samples to rock types is based on the total silica $\left(\mathrm{SiO}_{2}\right)$ and alkali $\left(\mathrm{Na}_{2} \mathrm{O}+\mathrm{K}_{2} \mathrm{O}\right)$

contents for which the spatial distribution of weight portions (in wt $\%$ ) across the sampling sites is also shown

materials from active geothermal sites to guarantee snowfree access to the volcanic material. From all three types of sampling sites, the same amounts of material were extracted $\left(\sim 0.002 \mathrm{~m}^{3}\right)$. Samples were stored in clean plastic bags until preparations for laboratory analyses started.

\section{Laboratory analyses}

\section{Methods}

Grain thermal conductivity of the volcanic materials was measured using a commercial device (TeKa 04 thermal conductivity meter) that uses a modified hot needle probe method as measuring principle. In contrast to the original and well-established hot needle probe method (Von Herzen

and Maxwell 1959) in which a thin, long heating source is inserted into the sample, TeKa 04 uses a disk-shaped device with the heating source mounted at its underside, which is placed on top of the sample.

For preparation, the volcanic materials were sieved. From the sieved samples, the $1-3 \mathrm{~mm}$ grain size fractions were extracted. For measurement, the material was filled into a container of known volume and fully saturated with water. Temperature was kept constant $\left(20^{\circ} \mathrm{C}\right)$ during measurements. Prior to the measurement, the probe was installed on the material inside the container and any remaining air is evacuated from the closed measurement system. It cannot be ruled out that the limitation of the sample to its $1-3 \mathrm{~mm}$ grain size fraction might impact the measurement somewhat, but we expect those impacts to be small as the majority of the samples fall within this grain size range. 
The results of the measurements represent the thermal conductivity of the composite of volcanic material and water. Following Farouki (1981), the bulk thermal conductivity $\left(k_{\mathrm{c}}\right)$ can be estimated by:

$k_{\mathrm{c}}=k_{\mathrm{g}}^{(1-p)} k_{\mathrm{w}}^{p}$,

which represents the geometric mean between the thermal conductivity of the grains $\left(k_{\mathrm{g}}\right)$ and the saturating water $\left(k_{\mathrm{w}}\right)$ weighed by porosity $(p)$. Thus, the grain thermal conductivity is given by:

$k_{\mathrm{g}}=\left(k_{\mathrm{c}} / k_{\mathrm{w}}^{p}\right)^{1 / 1-p}$.

A value of $k_{\mathrm{w}}=0.6 \mathrm{~W} \mathrm{~m}^{-1} \mathrm{~K}^{-1}$ was assumed in calculations. Porosity was calculated as:

$p=V_{\mathrm{w}} / V_{\mathrm{c}}$,

where the volume of the saturating water $\left(V_{\mathrm{w}}\right)$ was derived by weighing the measured material both in its saturated and in a dried-out state and the volume of the measured material $\left(V_{c}\right)$ is that of the container. Hereby, the density of the volcanic material is derived implicitly.

Grain thermal conductivity and grain density results of the sampled volcanic material are given in Table 1 . The chemical composition (ten major element oxides) of the volcanic material derived from X-ray fluorescence (XRF) analysis is given in Table 2 . Trace elements are given in the supplementary Table S1.

Based on the anhydrous weight portions of the major element oxides, the volcanic host rock type of each sample is identified using the relation between its total alkali $\left(\mathrm{Na}_{2} \mathrm{O}+\mathrm{K}_{2} \mathrm{O}\right)$ to silica $\left(\mathrm{SiO}_{2}\right)$ contents following the total alkali-silica (TAS) diagram classification introduced by Le Bas et al. (1986). The rock types are presented in Table 1.

\section{Results}

Measured grain thermal conductivity and grain density of the 43 samples show means of $1.43 \pm 0.38 \mathrm{Wm}^{-1} \mathrm{~K}^{-1}$ and $2487 \pm 452 \mathrm{~kg} \mathrm{~m}^{-3}$, respectively (Table 1). For individual samples, thermal conductivities range between $0.69 \mathrm{Wm}^{-1} \mathrm{~K}^{-1}$ (samples 5 and 39 ) and $2.33 \mathrm{Wm}^{-1} \mathrm{~K}^{-1}$ (sample 18). The relative variability in grain density is slightly smaller. Values range between $1081 \mathrm{~kg} \mathrm{~m}^{-3}$ (sample 5) and $3667 \mathrm{~kg} \mathrm{~m}^{-3}$ (sample 2). Characteristic spatial patterns across Iceland do not exist (Fig. 2). Just the spatial consistency of the absolute minima of both quantities at the location of sample 5 is noticeable. The significant correlation ( $r=0.66$ ) between grain thermal conductivity and grain density suggests a characteristic relationship between the two (Fig. 3).
Table 1 Grain thermal conductivity $\left(\mathrm{W} \mathrm{m}^{-1} \mathrm{~K}^{-1}\right)$ and grain density $\left(\mathrm{kg} \mathrm{m}^{-3}\right)$ of the investigated volcanic materials

\begin{tabular}{|c|c|c|c|}
\hline Sample & $\begin{array}{l}\text { Grain thermal } \\
\text { conductivity }\end{array}$ & Grain density & Rock type \\
\hline 1 & 1.454 & 2731 & $\mathrm{~S}_{1}$ \\
\hline 2 & 2.119 & 3667 & B \\
\hline 3 & 1.442 & 2524 & B \\
\hline 4 & 1.779 & 2865 & $\mathrm{Pc}$ \\
\hline 5 & 0.686 & 1081 & $\mathrm{~F}$ \\
\hline 6 & 1.476 & 2549 & $\mathrm{~S}_{3}$ \\
\hline 7 & 1.445 & 2462 & B \\
\hline 8 & 1.140 & 2457 & B \\
\hline 9 & 1.343 & 2667 & B \\
\hline 10 & 1.778 & 2858 & B \\
\hline 11 & 1.808 & 2453 & $\mathrm{O}_{1}$ \\
\hline 12 & 1.409 & 2681 & $\mathrm{~B}$ \\
\hline 13 & 1.584 & 2590 & B \\
\hline 14 & 2.089 & 2429 & $\mathrm{O}_{2}$ \\
\hline 15 & 1.065 & 3111 & B \\
\hline 16 & 1.095 & 2063 & $\mathrm{~B}$ \\
\hline 17 & 0.834 & 2249 & B \\
\hline 18 & 2.326 & 2935 & B \\
\hline 19 & 1.776 & 2602 & $\mathrm{Pc}$ \\
\hline 20 & 1.232 & 2656 & Pc \\
\hline 21 & 1.118 & 2533 & $\mathrm{Pc}$ \\
\hline 22 & 1.469 & 2771 & Pc \\
\hline 23 & 1.244 & 1931 & B \\
\hline 24 & 1.207 & 2943 & B \\
\hline 25 & 1.083 & 2022 & B \\
\hline 26 & 1.393 & 2554 & B \\
\hline 27 & 1.035 & 2244 & $\mathrm{O}_{2}$ \\
\hline 28 & 1.090 & 2134 & $\mathrm{R}$ \\
\hline 29 & 1.342 & 2634 & $\mathrm{O}_{1}$ \\
\hline 30 & 1.664 & 2579 & B \\
\hline 31 & 1.441 & 2774 & B \\
\hline 32 & 1.726 & 2703 & B \\
\hline 33 & 1.535 & 2143 & $\mathrm{O}_{1}$ \\
\hline 34 & 1.657 & 2779 & B \\
\hline 35 & 1.305 & 1930 & B \\
\hline 36 & 1.217 & 1966 & B \\
\hline 37 & 1.717 & 2947 & B \\
\hline 38 & 1.313 & 2044 & $\mathrm{O}_{1}$ \\
\hline 39 & 0.686 & 1518 & B \\
\hline 40 & 1.571 & 2781 & B \\
\hline 41 & 2.320 & 2838 & B \\
\hline 42 & 1.022 & 1878 & B \\
\hline 43 & 1.602 & 2647 & B \\
\hline
\end{tabular}

Rock types are derived from their total alkali to silica relations (Fig. 5): foidite $(\mathrm{F})$, picrobasalt $(\mathrm{Pc})$, basalt $(\mathrm{B})$, trachybasalt $\left(\mathrm{S}_{1}\right)$, trachyandesite $\left(\mathrm{S}_{3}\right)$, basaltic andesite $\left(\mathrm{O}_{1}\right)$, andesite $\left(\mathrm{O}_{2}\right)$, rhyolite $(\mathrm{R})$ 
Table 2 Major element oxides $\left(e_{i}\right.$ in wt\%) composition of the investigated volcanic materials. All iron content is displayed as $\mathrm{Fe}_{2} \mathrm{O}_{3}$

\begin{tabular}{|c|c|c|c|c|c|c|c|c|c|c|c|c|}
\hline Sample & $\begin{array}{l}e_{1} \\
\mathrm{SiO}_{2}\end{array}$ & $\begin{array}{l}e_{2} \\
\mathrm{TiO}_{2}\end{array}$ & $\begin{array}{l}e_{3} \\
\mathrm{Al}_{2} \mathrm{O}_{3}\end{array}$ & $\begin{array}{l}e_{4} \\
\mathrm{Fe}_{2} \mathrm{O}_{3}\end{array}$ & $\begin{array}{l}e_{5} \\
\mathrm{MnO}\end{array}$ & $\begin{array}{l}e_{6} \\
\mathrm{MgO}\end{array}$ & $\begin{array}{l}e_{7} \\
\mathrm{CaO}\end{array}$ & $\begin{array}{l}e_{8} \\
\mathrm{Na}_{2} \mathrm{O}\end{array}$ & $\begin{array}{l}e_{9} \\
\mathrm{P}_{2} \mathrm{O}_{5}\end{array}$ & $\begin{array}{l}e_{10} \\
\mathrm{~K}_{2} \mathrm{O}\end{array}$ & Tr. el & L.o.i \\
\hline 1 & 47.1 & 3.26 & 11.5 & 13.2 & 0.21 & 2.91 & 7.8 & 3.48 & 0.52 & 1.23 & 0.43 & 8.3 \\
\hline 2 & 43.2 & 1.80 & 15.3 & 12.3 & 0.20 & 5.62 & 11.6 & 2.53 & 0.26 & 0.45 & 0.26 & 6.4 \\
\hline 3 & 44.0 & 2.97 & 12.8 & 16.1 & 0.30 & 5.82 & 7.9 & 2.78 & 0.47 & 0.52 & 0.22 & 6.0 \\
\hline 4 & 41.3 & 2.21 & 15.8 & 14.1 & 0.24 & 4.74 & 10.5 & 2.47 & 0.27 & 0.24 & 0.23 & 7.9 \\
\hline 5 & 33.2 & 3.64 & 13.5 & 15.2 & 0.23 & 5.10 & 9.2 & 1.92 & 0.67 & 0.62 & 0.57 & 16.1 \\
\hline 6 & 53.0 & 1.47 & 13.9 & 9.1 & 0.21 & 2.13 & 4.4 & 4.88 & 0.35 & 1.80 & 0.45 & 8.3 \\
\hline 7 & 45.9 & 2.26 & 13.0 & 12.8 & 0.24 & 3.57 & 8.8 & 2.94 & 0.45 & 0.76 & 0.33 & 8.9 \\
\hline 8 & 40.7 & 3.35 & 13.2 & 15.9 & 0.26 & 6.02 & 8.0 & 0.75 & 0.37 & 0.12 & 0.18 & 11.1 \\
\hline 9 & 43.3 & 2.38 & 11.9 & 13.8 & 0.22 & 5.53 & 11.0 & 2.43 & 0.24 & 0.34 & 0.35 & 8.6 \\
\hline 10 & 39.8 & 2.46 & 10.8 & 13.8 & 0.21 & 4.51 & 10.1 & 2.47 & 0.28 & 0.44 & 0.34 & 14.8 \\
\hline 11 & 45.2 & 1.95 & 10.5 & 10.8 & 0.18 & 2.49 & 8.1 & 2.91 & 0.36 & 1.15 & 0.34 & 16.0 \\
\hline 12 & 42.5 & 1.83 & 12.7 & 14.1 & 0.23 & 5.45 & 9.4 & 1.80 & 0.19 & 0.27 & 0.38 & 11.1 \\
\hline 13 & 35.8 & 1.15 & 9.9 & 10.3 & 0.15 & 7.94 & 7.5 & 0.55 & 0.12 & 0.18 & 0.35 & 26.1 \\
\hline 14 & 51.6 & 2.95 & 11.0 & 16.3 & 0.11 & 2.43 & 2.4 & 0.80 & 0.25 & 0.24 & 1.23 & 10.7 \\
\hline 15 & 41.8 & 1.88 & 11.1 & 15.8 & 0.25 & 4.92 & 10.5 & 1.93 & 0.18 & 0.25 & 0.42 & 10.9 \\
\hline 16 & 37.8 & 1.80 & 10.3 & 15.3 & 0.23 & 4.39 & 9.8 & 1.76 & 0.17 & 0.24 & 0.39 & 17.9 \\
\hline 17 & 43.3 & 1.61 & 12.8 & 12.5 & 0.21 & 6.67 & 12.9 & 1.97 & 0.20 & 0.14 & 0.34 & 7.3 \\
\hline 18 & 42.0 & 1.89 & 10.9 & 15.5 & 0.24 & 5.31 & 10.3 & 2.06 & 0.24 & 0.27 & 0.37 & 11.0 \\
\hline 19 & 38.3 & 1.36 & 13.8 & 12.1 & 0.20 & 5.48 & 12.0 & 1.94 & 0.14 & 0.10 & 0.25 & 14.4 \\
\hline 20 & 36.9 & 2.39 & 14.6 & 14.4 & 0.23 & 5.81 & 8.3 & 1.26 & 0.27 & 0.23 & 0.36 & 15.2 \\
\hline 21 & 36.7 & 1.63 & 13.1 & 13.0 & 0.20 & 6.23 & 10.1 & 1.39 & 0.20 & 0.17 & 0.38 & 17.0 \\
\hline 22 & 36.4 & 2.17 & 14.4 & 14.5 & 0.23 & 4.65 & 9.9 & 1.80 & 0.30 & 0.22 & 0.50 & 14.9 \\
\hline 23 & 39.2 & 2.05 & 12.3 & 14.0 & 0.24 & 4.14 & 9.5 & 2.21 & 0.27 & 0.44 & 0.33 & 15.3 \\
\hline 24 & 39.6 & 1.85 & 11.5 & 13.7 & 0.22 & 5.75 & 11.2 & 1.70 & 0.18 & 0.19 & 0.38 & 13.7 \\
\hline 25 & 39.0 & 1.69 & 12.4 & 13.8 & 0.22 & 5.00 & 11.0 & 1.99 & 0.18 & 0.14 & 0.32 & 14.2 \\
\hline 26 & 42.4 & 2.49 & 14.7 & 12.7 & 0.23 & 3.28 & 7.5 & 2.55 & 0.45 & 0.81 & 0.35 & 12.5 \\
\hline 27 & 57.3 & 1.67 & 12.1 & 9.9 & 0.18 & 2.11 & 6.2 & 3.06 & 0.25 & 1.29 & 0.27 & 5.7 \\
\hline 28 & 68.0 & 0.98 & 11.1 & 4.7 & 0.12 & 0.69 & 2.9 & 3.69 & 0.21 & 2.12 & 0.21 & 5.3 \\
\hline 29 & 49.2 & 1.67 & 12.7 & 11.5 & 0.19 & 3.82 & 9.8 & 2.43 & 0.22 & 0.66 & 0.40 & 7.4 \\
\hline 30 & 43.6 & 2.82 & 10.5 & 17.0 & 0.26 & 4.38 & 8.1 & 2.38 & 0.31 & 0.50 & 0.47 & 9.7 \\
\hline 31 & 41.7 & 2.24 & 11.3 & 13.5 & 0.22 & 4.22 & 10.0 & 2.10 & 0.25 & 0.43 & 0.37 & 13.7 \\
\hline 32 & 39.8 & 2.03 & 14.3 & 13.2 & 0.22 & 3.91 & 10.0 & 1.95 & 0.25 & 0.24 & 0.27 & 13.9 \\
\hline 33 & 48.2 & 1.70 & 12.8 & 11.7 & 0.20 & 3.64 & 8.1 & 2.42 & 0.18 & 0.69 & 0.33 & 10.0 \\
\hline 34 & 41.6 & 1.81 & 13.2 & 13.1 & 0.22 & 5.05 & 10.9 & 1.84 & 0.17 & 0.23 & 0.33 & 11.6 \\
\hline 35 & 42.1 & 2.26 & 14.1 & 15.9 & 0.31 & 3.50 & 9.4 & 2.49 & 0.34 & 0.40 & 0.31 & 9.0 \\
\hline 36 & 44.0 & 2.24 & 14.4 & 13.3 & 0.26 & 2.93 & 7.3 & 2.47 & 0.35 & 0.70 & 0.31 & 11.8 \\
\hline 37 & 38.4 & 1.08 & 14.5 & 11.0 & 0.17 & 4.10 & 11.8 & 1.88 & 0.12 & 0.10 & 0.19 & 16.7 \\
\hline 38 & 45.4 & 1.47 & 14.2 & 9.9 & 0.16 & 2.54 & 7.4 & 2.29 & 0.18 & 0.92 & 0.29 & 15.2 \\
\hline 39 & 46.8 & 1.87 & 13.3 & 12.3 & 0.24 & 3.41 & 8.8 & 2.98 & 0.43 & 0.77 & 0.33 & 8.8 \\
\hline 40 & 43.1 & 2.31 & 12.1 & 14.6 & 0.22 & 4.97 & 11.1 & 2.16 & 0.26 & 0.24 & 0.41 & 8.6 \\
\hline 41 & 42.0 & 1.86 & 11.8 & 13.5 & 0.22 & 5.46 & 11.2 & 2.31 & 0.22 & 0.30 & 0.31 & 10.9 \\
\hline 42 & 42.7 & 2.48 & 13.3 & 13.1 & 0.23 & 3.33 & 8.0 & 2.58 & 0.42 & 0.69 & 0.31 & 12.8 \\
\hline 43 & 41.3 & 3.54 & 10.6 & 14.3 & 0.22 & 3.53 & 8.5 & 2.68 & 0.42 & 0.73 & 0.41 & 13.8 \\
\hline
\end{tabular}

The sum of all trace elements (Tr.el.) and the loss on ignition (L.o.i.) are given in addition
The geochemical compositions of the 43 samples are less diverse than their thermal conductivities and densities. The weight portions of the main components $\left(\mathrm{SiO}_{2}, \mathrm{Fe}_{2} \mathrm{O}_{3}\right.$ and $\mathrm{Al}_{2} \mathrm{O}_{3}$ ) scatter within narrow limits, albeit some exceptions
(Table 2). The silica content shows a mean of $43.1 \pm 6.1 \mathrm{wt} \%$ ( \pm one sigma). Only a limited number of examples for strongly negative or positive deviations exist. Overall data cover silica contents between 33.2 and $68.0 \mathrm{wt} \%$. The alkali 

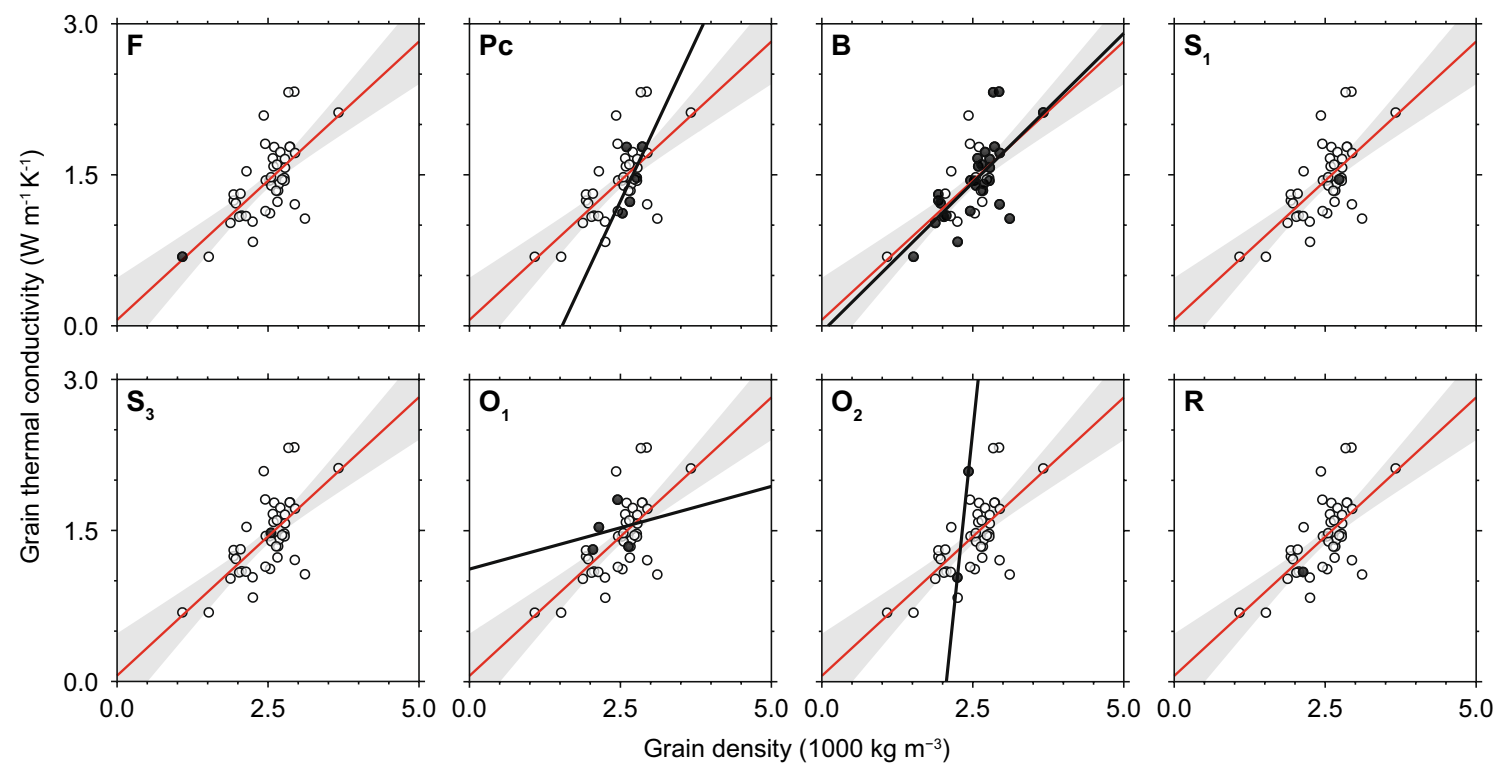

Fig. 3 Scatterplots between grain density and grain thermal conductivity of all 43 samples subdivided according to rock type, i.e., foidite $(\mathrm{F})$, picrobasalt $(\mathrm{Pc})$, basalt $(\mathrm{B})$, trachybasalt $\left(\mathrm{S}_{1}\right)$, trachyandesite $\left(\mathrm{S}_{3}\right)$, basaltic andesite (O1), andesite (O2) and rhyolite (R). In each plot, open circles represent the overall sample set, while filled black circles

content $\left(\mathrm{Na}_{2} \mathrm{O}+\mathrm{K}_{2} \mathrm{O}\right)$ shows a mean of $2.8 \pm 1.2 \mathrm{wt} \%$, with some apparent outliers. Values for individual samples range between 0.7 and $6.7 \mathrm{wt} \%$.

Geochemical compositions of the samples show a dominance of basalt with almost two-thirds of the samples belonging to this rock type (Table 1, Fig. 4). Basaltic materials dominate in all volcanic zones and belts of Iceland with only few exceptions (Fig. 2). In the WVZ, picrobasalt is the dominating rock type. In the southern EVZ, more evolved and differentiated rock types occur. Silica content $\left(\mathrm{SiO}_{2}\right)$ is spatially uniformly distributed even if lowest weight portions concentrate in the WVZ (Fig. 2). Samples with extremely high silica contents are limited to the NVZ (samples 27 and 28 , Fig. 2). Samples with a high alkali content $\left(\mathrm{Na}_{2} \mathrm{O}+\mathrm{K}_{2} \mathrm{O}\right)$ occur in the southern EVZ (samples 1 and 6) and at the Askja caldera (sample 28, Fig. 2).

When classifying the samples into different rock types, relationships between geochemical composition on the one hand and grain thermal conductivity and grain density on the other hand are noticeable (Fig. 4). Data suggest a decrease of density with further evolution of the rock type from mafic to felsic. For thermal conductivity, such a trend is mostly obscured by a small number of samples at the felsic edge of the range of rock types. Accordingly, the laboratory results also suggest a variation of the above-described relationship between grain density and grain thermal conductivity with rock type (Fig. 3): the increase of thermal conductivity with density is higher for picrobasalt and andesite than for the represent samples of the respective rock type. The red regression line indicates the best fit between grain density and grain thermal conductivity for all 43 samples with its $95 \%$ significance range indicated by grey shading. The black regression line indicates the best fit for samples of the respective rock type

overall sample set, whilst it is lower for basaltic andesite. The comparably limited number of all rock type subsets, except for basalt, inhibits any statistically significant inference of characteristic relationships.

In line with this, correlations between the weight portions of individual major element oxides and both the grain thermal conductivity itself and the residuals of the grain density-thermal conductivity relation (cf. Fig. 3) are generally weak (Table 3 ). Significant correlations occur only for partial correlations, which mask out secondary influences by other than the considered oxide itself. $\mathrm{MnO}$ is negatively related to grain thermal conductivity, while $\mathrm{Na}_{2} \mathrm{O}$ shows a positive relation. $\mathrm{CaO}$ and $\mathrm{Na}_{2} \mathrm{O}$ are positively related to the residuals of the grain density-thermal conductivity relation.

\section{Development of thermal conductivity models}

\section{Model description}

We propose four different predictive models (A, B, C1 and $\mathrm{C} 2$ ) to estimate grain thermal conductivities from rock properties and compositional data. These models are based on a regression analysis of the data listed in Tables 1 and 2. We further calculate bulk thermal conductivity of a volcanic deposit with variable pore space and water saturation. 

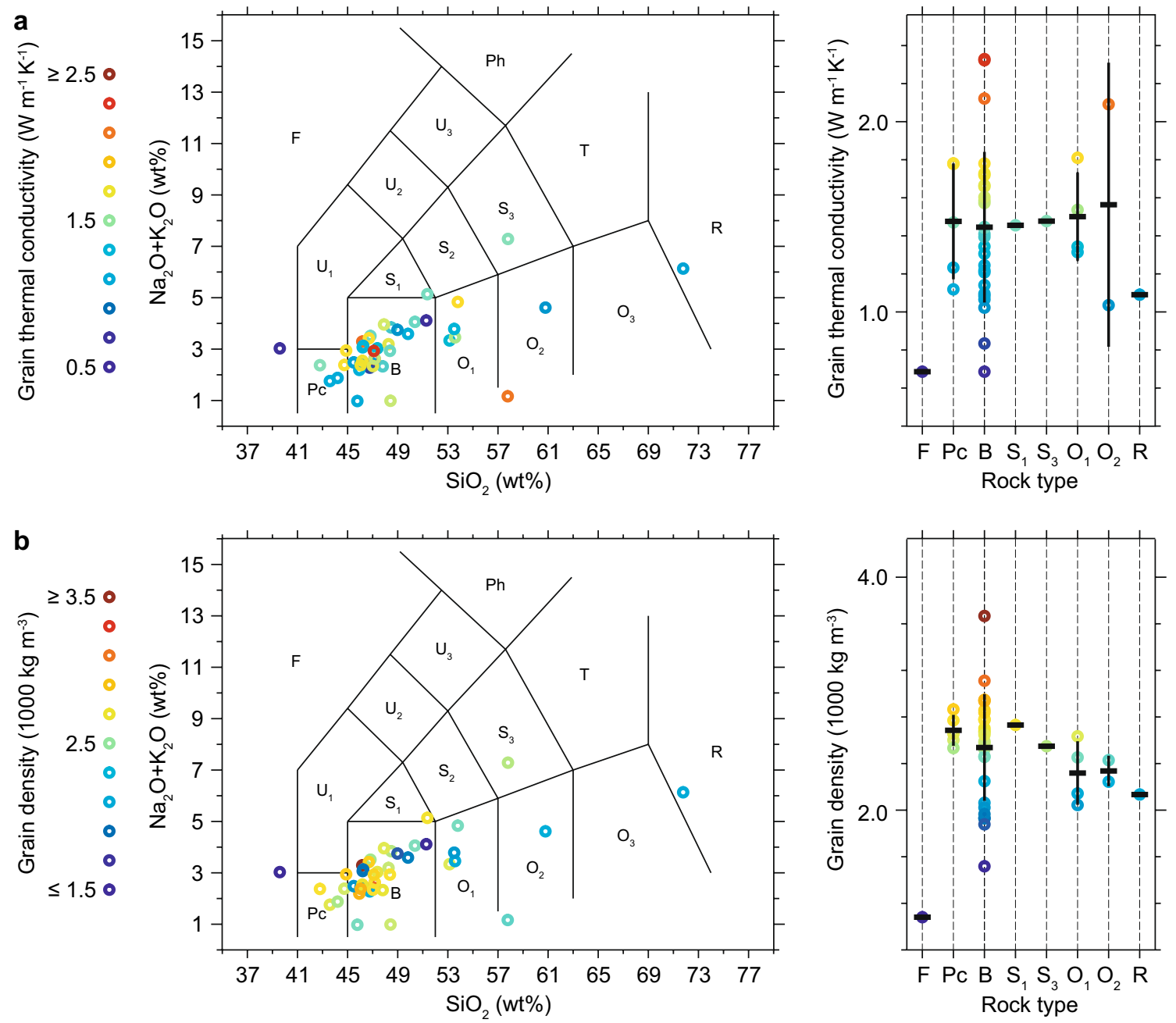

Fig. 4 Samples plotted in the total alkali-silica diagram (Le Bas et al. 1986) for identification of rock types: foidite $(\mathrm{F})$, picrobasalt $(\mathrm{Pc})$, basanite/tephrite $\left(\mathrm{U}_{1}\right)$, phonotephrite $\left(\mathrm{U}_{2}\right)$, tephriphonolite $\left(\mathrm{U}_{3}\right)$, phonolite $(\mathrm{Ph})$, basalt $(\mathrm{B})$, trachybasalt $\left(\mathrm{S}_{1}\right)$, basaltic trachyandesite $\left(\mathrm{S}_{2}\right)$, trachyandesite $\left(\mathrm{S}_{3}\right)$, trachyte/trachydacite $(\mathrm{T})$, basaltic andesite $\left(\mathrm{O}_{1}\right)$, andesite $\left(\mathrm{O}_{2}\right)$, dacite $\left(\mathrm{O}_{3}\right)$ and rhyolite $(\mathrm{R})$. Samples are shown in color codes for grain thermal conductivity (a) and grain density (b) of the volcanic material. The graphs on the right show the distributions of grain thermal conductivity and grain density according to rock type. The thick black bars indicate the mean while the whiskers represent a range of \pm one sigma standard deviation
In model $\mathrm{A}$, grain thermal conductivity $\left(k_{\mathrm{g}, \mathrm{A}}\right)$ is only a linear function of density (Table 1):

$k_{\mathrm{g}, \mathrm{A}}=c_{\mathrm{A}, 0}+c_{\mathrm{A}, 1} \cdot \rho_{\mathrm{g}}$.

In model $\mathrm{B}$, grain thermal conductivity $\left(k_{\mathrm{g}, \mathrm{B}}\right)$ is a function of the major element oxides $\left(e_{\mathrm{i}}\right.$ in wt $\%$; Table 2$)$ :

$k_{\mathrm{g}, \mathrm{B}}=c_{\mathrm{B}, 0}+\sum_{i}\left(c_{\mathrm{B}, i} \cdot e_{i}\right)$.

The coefficients $c_{\mathrm{A}, i}$ and $c_{\mathrm{B}, i}$ are shown in Table 4 and are determined from data in Tables 1 and 2.

Other than models A and B, models $\mathrm{C} 1$ and $\mathrm{C} 2$ do not directly estimate grain thermal conductivity, but aim at explaining the residuals of model A. Hence, the predictand of model $\mathrm{A}\left(k_{\mathrm{g}, \mathrm{A}}\right)$ is added as a predictor.

In model $\mathrm{C} 1$, grain thermal conductivity $\left(k_{\mathrm{g}, \mathrm{Cl}}\right)$ is the sum of $k_{\mathrm{g}, \mathrm{A}}$ and a function of the major element oxides $\left(e_{i}\right.$ in wt $\%$; Table 2):

$k_{\mathrm{g}, \mathrm{C} 1}=k_{\mathrm{g}, \mathrm{A}}+c_{\mathrm{C} 1,0}+\sum_{i}\left(c_{\mathrm{C} 1, i} \cdot e_{i}\right)$.

In model $\mathrm{C} 2$, grain thermal conductivity $\left(k_{\mathrm{g}, \mathrm{C} 2}\right)$ is the sum of $k_{\mathrm{g}, \mathrm{A}}$ and a function of anhydrous weight portions of the three major element oxides ( $e_{\text {anhyd, } i}$ in wt $\%$ ) that were previously used to determine rock types $\left(\mathrm{SiO}_{2}, \mathrm{Na}_{2} \mathrm{O}\right.$ and $\mathrm{K}_{2} \mathrm{O}$; cf. Sect. 3.1): 
Table 3 Pearson (partial) correlations between weight portions of the major element oxides and grain thermal conductivities (MEO vs. TC) or between weight portions of the major element oxides and the residuals of the grain density-thermal conductivity relation (cf. Fig. 3, $\mathrm{MEO}$ vs. $\mathrm{TC}_{\mathrm{res}}$ )

\begin{tabular}{|c|c|c|}
\hline Major element oxide & MEO vs. TC & MEO vs. $\mathrm{TC}_{\mathrm{res}}$ \\
\hline $\mathrm{SiO}_{2}$ & $-0.03(-0.10)$ & $0.03(-0.14)$ \\
\hline $\mathrm{TiO}_{2}$ & $-0.04(0.13)$ & $0.07(-0.06)$ \\
\hline $\mathrm{Al}_{2} \mathrm{O}_{3}$ & $-0.09(0.03)$ & $-0.10(-0.14)$ \\
\hline $\mathrm{Fe}_{2} \mathrm{O}_{3}$ & $0.10(0.09)$ & $0.07(0.00)$ \\
\hline $\mathrm{MnO}$ & $-0.18(-0.35)$ & $-0.17(-0.24)$ \\
\hline $\mathrm{MgO}$ & $0.06(0.09)$ & $-0.19(-0.19)$ \\
\hline $\mathrm{CaO}$ & $0.08(-0.19)$ & $-0.17(-0.30)$ \\
\hline $\mathrm{Na}_{2} \mathrm{O}$ & $-0.05(\underline{0.42})$ & $0.01(\underline{0.34})$ \\
\hline $\mathrm{P}_{2} \mathrm{O}_{5}$ & $-0.25(-0.21)$ & $0.02(0.11)$ \\
\hline $\mathrm{K}_{2} \mathrm{O}$ & $-0.18(-0.19)$ & $-0.00(-0.29)$ \\
\hline
\end{tabular}

The partial correlation for any major element oxide is calculated with the effects of the respective other major element oxides removed. Underlined correlation coefficients indicate significance on the $90 \%$ level

Table 4 Coefficients $\left(c_{\mathrm{A}, i}, c_{\mathrm{B}, i}, c_{\mathrm{C} 1, i}, c_{\mathrm{C} 2, i}\right)$ of the grain thermal conductivity regression models

\begin{tabular}{llrrl}
\hline$I$ & $c_{A, i}$ (Eq. 4) & \multicolumn{1}{c}{$c_{B, i}$ (Eq. 5) } & \multicolumn{1}{c}{$c_{C l, i}$ (Eq. 6) } & \multicolumn{1}{c}{$c_{C 2, i}$ (Eq. 7) } \\
\hline 0 & 0.00997 & 2.09369 & 2.44766 & -0.71284 \\
1 & 0.00057 & -0.01044 & -0.01242 & 0.01357 \\
2 & - & 0.18029 & -0.07754 & - \\
3 & - & 0.00771 & -0.03401 & - \\
4 & - & 0.04848 & -0.00166 & - \\
5 & - & -6.26216 & -3.14540 & - \\
6 & - & 0.03798 & -0.06942 & - \\
7 & - & -0.06224 & -0.08595 & - \\
8 & - & 0.58321 & 0.34579 & 0.06133 \\
9 & - & -1.48493 & 0.68928 & - \\
10 & - & -0.81754 & -0.97951 & -0.19125 \\
\hline
\end{tabular}

$k_{\mathrm{g}, \mathrm{C} 2}=k_{\mathrm{g}, \mathrm{A}}+c_{\mathrm{C} 2,0}+c_{\mathrm{C} 2,1} \cdot e_{\mathrm{anhyd}, 1}+c_{\mathrm{C} 2,8} \cdot e_{\mathrm{anhyd}, 8}+c_{\mathrm{C} 2,10} \cdot e_{\mathrm{anhyd}, 10} \cdot$

The coefficients $c_{\mathrm{C} 1, i}$ and $c_{\mathrm{C} 2, i}$ are shown in Table 4 and are again determined from data in Tables 1 and 2 .

On the basis of Eq. (1), bulk thermal conductivity of a volcanic deposit $\left(k_{\mathrm{d}}\right)$ can be calculated from:

$k_{\mathrm{d}}(p, s)=k_{\mathrm{g}}^{(1-p)} k_{\mathrm{w}}^{p \cdot s} k_{\mathrm{a}}^{p \cdot(1-s)}$,

where $k_{\mathrm{a}}\left(0.0262 \mathrm{~W} \mathrm{~m}^{-1} \mathrm{~K}^{-1}\right)$ is the air thermal conductivity.

The three components are weighted according to their respective volume portions in the deposit, which are calculated from the effective porosity of the deposit $(p)$ and from the degree of water saturation of the related pore space $(s)$. As porosity and water saturation of the deposit are generally unknown, they were treated as variables here. By varying both of them between 0.0 and 1.0 (0-100\%), we calculated the full range of bulk thermal conductivities of a deposit of volcanic material.

\section{Model performance}

Model performance is assessed on the basis of three different statistical measures. First, we calculate the root mean square (RMS) error between measured and modeled $k_{\mathrm{g}}$. Second, we calculate the percentage of the variance in measured $k_{\mathrm{g}}$ which is explained by each model, i.e., we calculate $R^{2}$. And third, we calculate the slope of a linear fit to a scatter plot between measured and modeled $k_{\mathrm{g}}$.

Results indicate that the four regression models $\mathrm{A}$, B, C1 and C2 show distinctly different performances (Fig. 5). Model A ( $\left.k_{\mathrm{g}, \mathrm{A}}\right)$ explains $43.4 \%$ of the variance in measured $k_{g}$. The RMS error between $k_{\mathrm{g}, \mathrm{A}}$ and $k_{\mathrm{g}}$ of $\pm 0.282 \mathrm{~W} \mathrm{~m}^{-1} \mathrm{~K}^{-1}$ indicates an accuracy of modeled $k_{\mathrm{g}, \mathrm{A}}$ of $\sim \pm 20 \%$. Model B, as the least accurate model, explains only $33.2 \%$ of the variance. Modeled $k_{\mathrm{g}, \mathrm{B}}$ show an RMS error of $\pm 0.306 \mathrm{Wm}^{-1} \mathrm{~K}^{-1}$ and thus an accuracy of $\sim 21 \%$. The best performing models are $\mathrm{C} 1$ and $\mathrm{C} 2$. Model $\mathrm{C} 1$ explains $58.9 \%$ of the variance in measured $k_{\mathrm{g}}$. The RMS error is as low as $\pm 0.240 \mathrm{Wm}^{-1} \mathrm{~K}^{-1}(\sim \pm 17 \%)$. Model $\mathrm{C} 2$ explains $44.9 \%$ of the variance in measured $k_{\mathrm{g}}$ and an RMS error of $\pm 0.279 \mathrm{Wm}^{-1} \mathrm{~K}^{-1}(\sim \pm 19 \%)$. The thermal conductivities calculated according to all four models show the same kind of systematic error, even though at different magnitudes (Fig. 5). In general, smaller values $\left(<\sim 1.5 \mathrm{Wm}^{-1} \mathrm{~K}^{-1}\right)$ are overestimated, while larger values $\left(>\sim 1.5 \mathrm{Wm}^{-1} \mathrm{~K}^{-1}\right)$ are underestimated. In case of model $\mathrm{B}$, this systematic error is more pronounced. The slope of its linear fit is only 0.33 (Fig. 5). For model C1 the slope reaches 0.59 .

\section{Model feasibility test}

\section{Procedure}

In the following, we evaluate to which extent it is feasible to carry out the thermal conductivity modeling procedure described above, based on limited geochemical input data derived from the literature. For this test, we use major element oxides (Table 5) from the Eyjafjallajökull 2010 (EYV10) and the Grímsvötn 2011 (GRV11) eruptions as direct input in models B, C1 and C2. Apart from the geochemical data, grain densities of the volcanic materials are needed as input in models $\mathrm{A}, \mathrm{C} 1$ and $\mathrm{C} 2$. To derive grain densities from the available geochemical compositions, characteristic median tephra densities for each igneous rock 
Fig. 5 Performance of the grain thermal conductivity regression models (model name given in the upper left of each panel) expressed as scatter plots comparing modeled to measured grain thermal conductivities $\left(k_{\mathrm{g}}\right.$, cf. Table 1$)$ of the volcanic materials. One-one relations are indicated as thin black lines. Actual relations between modeled and measured data are represented by linear fits (red lines), with the statistical measures slope $(\beta), R^{2}$ and root mean square error (RMSE) given in the lower right of each panel
Table 5 Geochemical compositions of Eyjafjallajökull and Grímsvötn volcanic materials
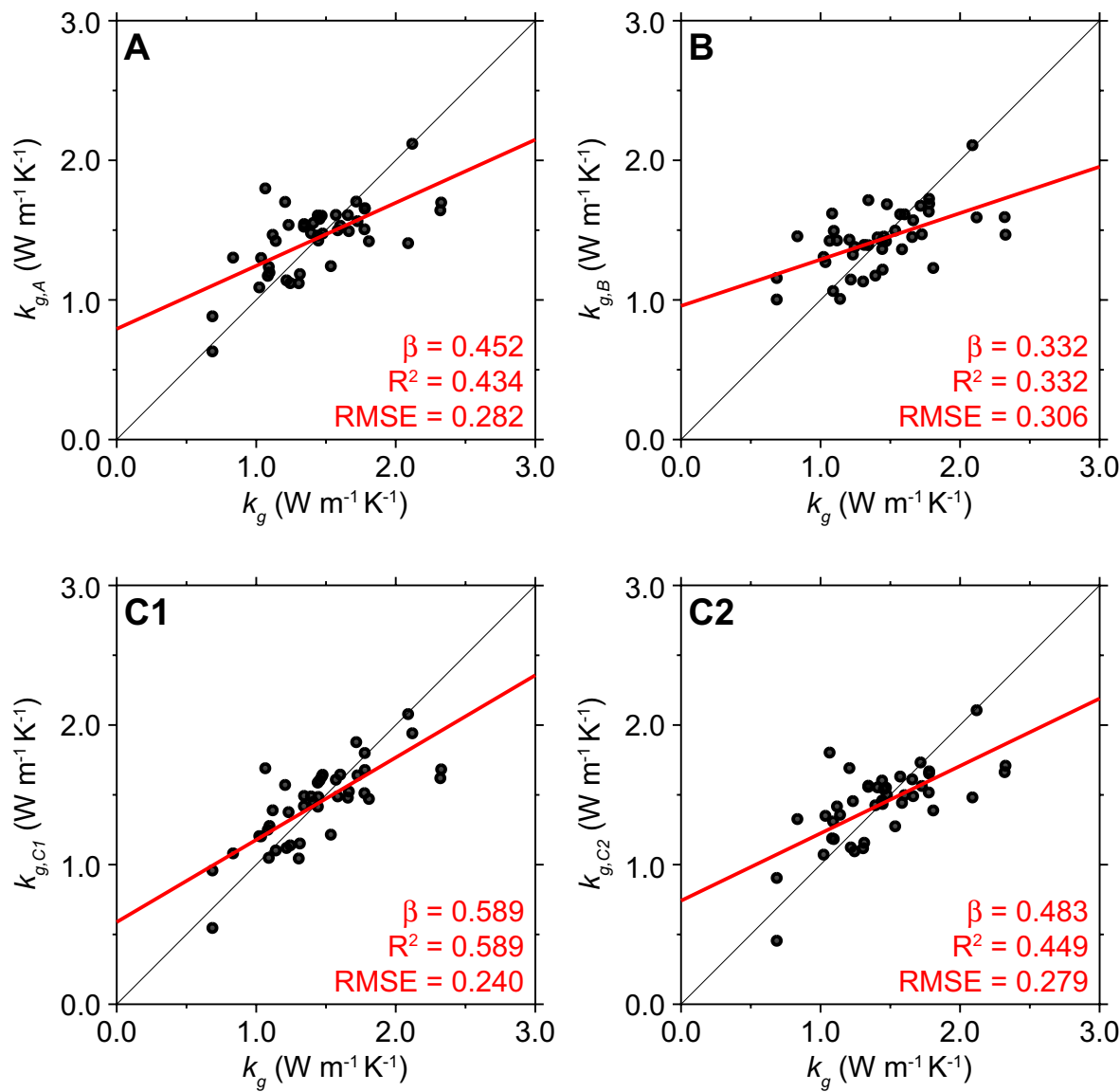

\begin{tabular}{lrc}
\hline Oxides & EYV10 & GRV11 \\
\hline $\mathrm{SiO}_{2}$ & 60.23 & 50.20 \\
$\mathrm{TiO}_{2}$ & 1.47 & 2.85 \\
$\mathrm{Al}_{2} \mathrm{O}_{3}$ & 14.55 & 13.46 \\
$\mathrm{FeO}$ & 8.96 & 13.64 \\
$\mathrm{MnO}$ & 0.27 & 0.23 \\
$\mathrm{MgO}$ & 1.39 & 5.58 \\
$\mathrm{CaO}$ & 4.11 & 9.90 \\
$\mathrm{Na}_{2} \mathrm{O}$ & 5.33 & 2.78 \\
$\mathrm{P}_{2} \mathrm{O}_{5}$ & 0.47 & - \\
$\mathrm{K}_{2} \mathrm{O}$ & 2.27 & 0.55 \\
\hline
\end{tabular}

Major element oxides (anhydrous wt\%) are given for trachyandesitic material of the Eyjafjallajökull 2010 eruption (EYV10; Borisova et al. 2012) and for basaltic material of the Grímsvötn 2011 eruption (GRV11; Olsson et al. 2013) type (Hasterok and Webb 2017) were interpolated over the entire TAS diagram range using ordinary kriging (Fig. 6). In that way, grain densities can be determined from anhydrous weight portions of the $\mathrm{SiO}_{2}, \mathrm{Na}_{2} \mathrm{O}$ and $\mathrm{K}_{2} \mathrm{O}$ content only.

In the feasibility test, we first compare the performances of all four regression models in calculating grain thermal conductivity $\left(k_{\mathrm{g}}\right)$ of the two volcanic materials. We further compare the modeled $k_{\mathrm{g}}$ to the measured thermal conductivities of samples 6 and 8 which were taken at the calderas of Eyjafjallajökull and Grímsvötn, respectively (Fig. 2). Second, we calculate the ranges of possible bulk thermal conductivities $k_{\mathrm{d}}$ for any related deposit (Eq. 8).

The performance of the four regression models is assessed in terms of their modeling uncertainty, i.e., the uncertainty which they introduced into modeled $k_{\mathrm{g}}$. It is described by confidence intervals which are calculated individually for any $k_{\mathrm{g}, \mathrm{MOD}, i}$ according to:

$\left[k_{\mathrm{g}, \mathrm{MOD}, i} \pm t_{\alpha / 2, n-n_{\text {coef }}} \mathrm{SE}_{\mathrm{MOD}} \sqrt{x_{i}\left(X^{T} X\right)^{-1} x_{i}^{T}}\right]$.

Herein, MOD indicates the respective model (A, B, C1 or C2) and $i$ the volcanic material (EYV10 and GRV11). $t_{\alpha / 2, n-n_{\text {coef }}}$ is the cutoff value in a Student's $t$ distribution 

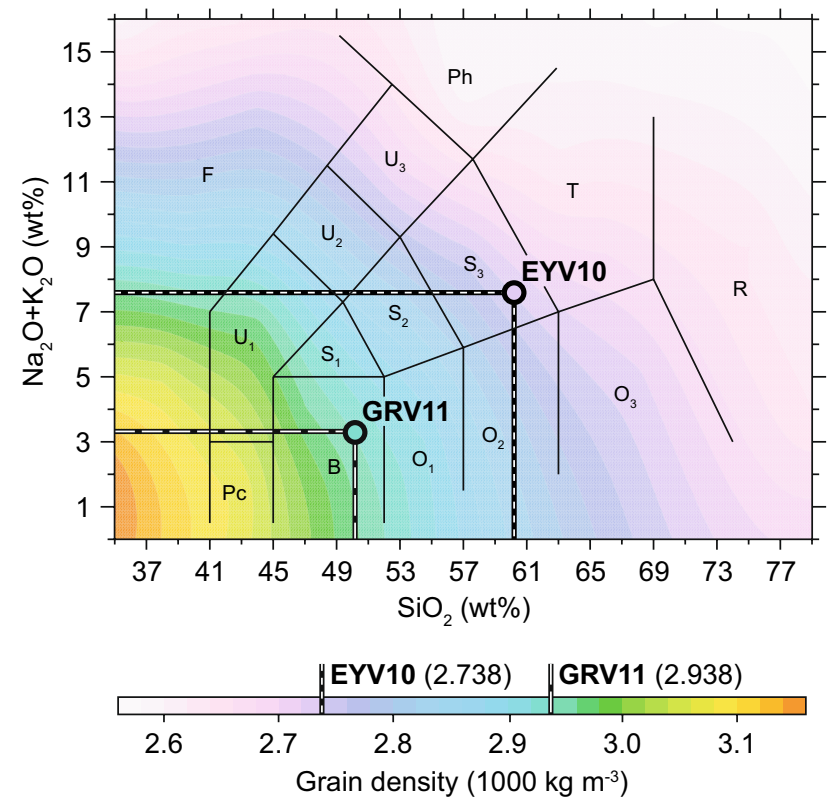

Fig. 6 Continuous, idealized grain densities of volcanic materials (color code) across igneous rock types displayed in the frame of a total alkali-silica diagram (Le Bas et al. 1986). The density field has been interpolated from point values of median densities per rock type given by Hasterok and Webb (2017) using ordinary kriging. Locations of the EYV10 and GRV11 volcanic materials are indicated by open circles. Naming of the rock type fields is according to Fig. 4

for a probability $\alpha=0.05$ and $n-n_{\text {coef }}$ degrees of freedom, with $n=43$ being the number of samples used for model calibration and $n_{\text {coef }}$ the number of coefficients of the respective model ( 2 for model A, 11 for model $\mathrm{B}, 13$ for model $\mathrm{C} 1$ and 6 for model $\mathrm{C} 2$ ). SE is the standard error of the respective model. $x_{i}$ is the matrix of input variables to the respective model containing the individual values related to volcanic material $i$ for calculation of $k_{\mathrm{g}, \mathrm{MOD}, i} . X$ is the matrix of input variables containing the values related to all 43 samples used for calibration of the respective regression model.

For the most feasible model, we also calculate the sensitivities of modeled $k_{\mathrm{g}}$ to perturbations of the values of the respective input variables to assess the impact of potential inaccuracies of these values. The sensitivities are calculated by varying the values of the input variables within a range of $\pm 5 \%$, which represents a rather conservative estimate. XRF analysis, which determines the weight portions of the major elements oxides, usually achieves accuracies with error ranges well below $1 \%$ regarding major element oxides (Jenkins 1999). For grain density, the data of Hasterok and Webb (2017; Fig. 6) suggest a spread of approximately $\pm 3 \%$ between the median density of each rock type and the associated upper or lower 5 th percentile.
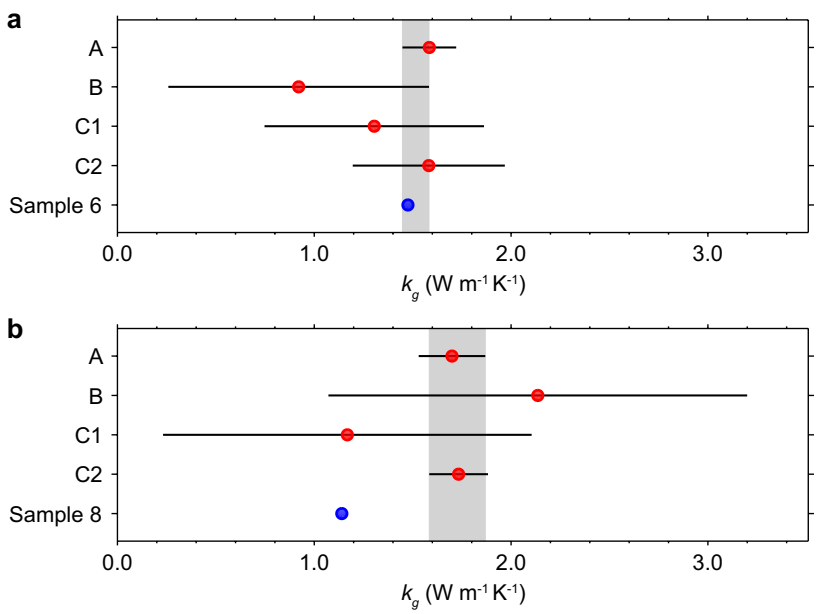

Fig. 7 Comparison of EYV10 (a) and GRV11 grain thermal conductivities (b) as calculated by the four regression models (model name given at the $y$-axis). Model results (red dots) are given together with their individual 95\% confidence intervals (thin black lines). Measured grain thermal conductivities of sample 6 (taken at Eyjafjallajökull caldera) and of sample 8 (taken at Grímsvötn caldera) are given for comparison (blue dots)

\section{Results}

The geochemical compositions EYV10 and GRV11 (Table 5, Fig. 6) characterize the volcanic materials as trachyandesitic and basaltic. The interpolation from point values of median densities per rock type by ordinary kriging assigns grain densities of $2738 \mathrm{~kg} \mathrm{~m}^{-3}$ (EYV10) and $2938 \mathrm{~kg} \mathrm{~m}^{-3}$ (GRV11), respectively, to these materials.

Model A and model C2 deliver comparable results in modeling grain thermal conductivities, while the results of calculations with models B and C1 deviate considerably (Fig. 7). The uncertainties, i.e., the $95 \%$ confidence intervals, of the thermal conductivities calculated using models $\mathrm{B}$ and $\mathrm{C} 1$ are in the same order of magnitude. The uncertainties of thermal conductivities calculated using models $\mathrm{A}$ and $\mathrm{C} 2$, in contrast, are up to one order of magnitude smaller. While the $95 \%$ confidence intervals of $k_{\mathrm{g}, \mathrm{B}}$ amount to $\pm 0.662 \mathrm{Wm}^{-1} \mathrm{~K}^{-1}$ (EYV10) and $\pm 1.064 \mathrm{Wm}^{-1} \mathrm{~K}^{-1}$ (GRV11), those of $k_{\mathrm{g}, \mathrm{C} 2}$ are distinctly smaller at just $\pm 0.386 \mathrm{Wm}^{-1} \mathrm{~K}^{-1}$ (EYV10) and $\pm 0.149 \mathrm{Wm}^{-1} \mathrm{~K}^{-1}$ (GRV11) (Fig. 7).

Based on the four predictive values for $k_{\mathrm{g}}$ of each volcanic material in combination with their respective confidence intervals, it is possible to identify a range of thermal conductivities covered by all four confidence intervals. When accepting the four predictive values as equally reliable, this range (indicated by grey shading in Fig. 7) might be interpreted as that one in which the actual value of $k_{\mathrm{g}}$ can be found with the highest probability. For both volcanic materials, only the predictive values of models A and C2 lie within 
this range. As model $\mathrm{C} 2$ shows the better model performance (Fig. 5) it is rated as the most feasible model. It combines a good model performance with the second smallest range of model uncertainty. In addition, the model sensitivity analysis suggests only a minor sensitivity of $k_{\mathrm{g}, \mathrm{C} 2}$ to the accuracy of its predictor variables (Table 6). Combined sensitivity to all four predictors only reach $\pm 0.093 \mathrm{Wm}^{-1} \mathrm{~K}^{-1}$ in case of the EYV10 material and $\pm 0.092 \mathrm{Wm}^{-1} \mathrm{~K}^{-1}$ in case of the GRV11 material. This means that a simultaneous variation of all four predictor variables (each within a $\pm 5.0 \%$ range) only results in a relative variability of $k_{\mathrm{g}, \mathrm{C} 2}$ of $\pm 5.9 \%$ (EYV10) and $\pm 5.3 \%$ (GRV11). Individual sensitivities are largest for density in case of both volcanic materials. For the EYV10 material, $\mathrm{a} \pm 5.0 \%$ perturbation of density leads to an equal perturbation in $k_{\mathrm{g}, \mathrm{C} 2}$. For the GRV11 material, $\mathrm{a} \pm 5.0 \%$ perturbation of density leads to a slightly smaller perturbation in $k_{\mathrm{g}, \mathrm{C} 2}$ of $4.9 \%$. Distinctly smaller impact of perturbation of the weight portions of $\mathrm{SiO}_{2}, \mathrm{Na}_{2} \mathrm{O}$ and $\mathrm{K}_{2} \mathrm{O}$ is observable, with $\pm 5.0 \%$ perturbations of the major element oxide's weight portion leading to perturbations in $k_{\mathrm{g}, \mathrm{C} 2}$ of just between $\pm 0.3 \%\left(\mathrm{~K}_{2} \mathrm{O}, \mathrm{GRV} 11\right)$ and $\pm 2.6 \%\left(\mathrm{SiO}_{2}\right.$, EYV10) (Table 6).

Comparing the modeled $k_{\mathrm{g}}$ of the EYV10 and GRV11 materials to their measured counterparts, i.e., samples 6 and 8, reveals a partly inconsistent result. Sample 6 from Eyjafjallajökull has been identified as trachyandesitic (Table 1). Also, the chemical composition of the EYV10 material suggests trachyandesitic material. The alkali-silica relations of both volcanic materials (Tables 2, 5) are similar at 0.126 , even though the individual weight portions are slightly lower in sample 6 . The measured grain density of sample 6 is only slightly lower $(\sim 7 \%)$ than the one assumed for the EYV10 material (Table 1, Fig. 6). Accordingly, the measured grain thermal conductivity of sample 6 lies close to $k_{\mathrm{g}, \mathrm{C} 2}$ of the EYV10 material (Fig. 7). This supports the reliability of the thermal conductivity model $\mathrm{C} 2$. The comparison between

Table 6 Sensitivity of the grain thermal conductivity of a volcanic material calculated with model $\mathrm{C} 2\left(k_{\mathrm{g}, \mathrm{C} 2}\right)$ to $\mathrm{a} \pm 5 \%$ variability of the predictor variables

\begin{tabular}{lll}
\hline Predictor variable & EYV10 & GRV11 \\
\hline Density & $0.079(5.0 \%)$ & $0.084(4.9 \%)$ \\
$\mathrm{SiO}_{2}$ & $0.041(2.6 \%)$ & $0.034(2.0 \%)$ \\
$\mathrm{Na}_{2} \mathrm{O}$ & $0.016(1.0 \%)$ & $0.009(0.5 \%)$ \\
$\mathrm{K}_{2} \mathrm{O}$ & $0.022(1.4 \%)$ & $0.005(0.3 \%)$ \\
$\mathrm{All}$ & $0.093(5.9 \%)$ & $0.092(5.3 \%)$ \\
\hline
\end{tabular}

Calculations are performed exemplarily for EYV10 and GRV11 volcanic materials. Absolute sensitivities $\left(\mathrm{W} \mathrm{m}^{-1} \mathrm{~K}^{-1}\right)$ are given together with relative sensitivities (in parenthesis). The total sensitivity (given in the lowermost row) assumes independence of the individual sensitivities from each other and is calculated using quadratic propagation sample 8 and the GRV11 material, on the other hand, yields less convincing results. Both volcanic materials are identified as basaltic but sample 8 is close to picrobasaltic. Their alkali-silica relations differ by a factor of five due to the very low alkali content in sample 8 (Tables 2,5 ). The grain densities are also considerably different. Sample 8 should have a rather high grain density of $>3000 \mathrm{~kg} \mathrm{~m}^{-3}$ according to Fig. 6, similar to the assumed density of the GRV11 material. However, the measured grain density of sample 8 is only $2457 \mathrm{~kg} \mathrm{~m}^{-3}$ (Table 1 ), which is very low for an almost picrobasaltic material. Consequently, the measured grain thermal conductivity of sample 8 is distinctly smaller than $k_{\mathrm{g}, \mathrm{C} 2}$ of the GRV11 material (Fig. 7). This indicates potentially misleading influences of grain density.

The possible ranges of bulk thermal conductivities of deposits of the EYV10 and GRV11 materials $\left(k_{\mathrm{d}}\right)$ are large but show clear relations to the respective thermal conductivities of the grains, which constitute the deposit. In general, bulk thermal conductivities are confined to the interval $\left.] 0.0262, k_{\mathrm{g}, \mathrm{C} 2}\right]$ (Fig. 8). The theoretical minimum $\left(k_{\mathrm{d}}=k_{\mathrm{a}}=0.0262 \mathrm{Wm}^{-1} \mathrm{~K}^{-1}\right)$ which represents quasi-complete insulation cannot be reached. It would require a porosity $p=100 \%$ without any water saturation at all $(s=0 \%)$, implying the absence of any volcanic material or porefilling water. The maximum $\left(k_{\mathrm{d}}=k_{\mathrm{g}, \mathrm{C} 2}\right)$, in turn, requires the absence of any pore space $(p=0 \%)$ and thus a solid, non-porous rock layer. A further boundary exists for the theoretical combination of $p=100 \%$ and $s=100 \%$ which would correspond to a pure water layer with a thermal conductivity $k_{d}=k_{w}=0.6 \mathrm{~W} / \mathrm{mK}$. The actual values of $k_{\mathrm{d}}$ span between these fixed edges. Thereby, the importance of $s$ for $k_{\mathrm{d}}$ increases with $p$ (Fig. 8). For volcanic deposits with little porosity, the degree of water saturation only has a negligible influence on $k_{\mathrm{d}}$. The higher the porosity, the more important is how much of the pore space is filled with water. Thereby it is important to point out that in a dry deposit $k_{\mathrm{d}}$ is characteristically reduced by one half (related to the maximum $k_{\mathrm{d}}=k_{\mathrm{g}, \mathrm{C} 2}$, i.e., to a solid rock layer) at a porosity of $\sim 16 \%$, independent of $k_{\mathrm{g}, \mathrm{C} 2}$. For a completely water-saturated deposit of EYV10 material, the halving occurs not until $p=72 \%$ while for a completely water-saturated deposit of GRV11 material porosity only needs to reach $65 \%$ to achieve a halving of $k_{d}$ (Fig. 8). This shows that the decrease of $k_{\mathrm{d}}$ with increasing $p$ in completely water-saturated deposits is more pronounced for deposits of high-conductive volcanic materials than for deposits of low-conductive volcanic materials.

The $95 \%$ confidence intervals of $k_{\mathrm{d}}$ increase with decreasing porosity (Fig. 8). The degree of water saturation is of minor importance regarding the confidence intervals, but increases with porosity. For highly porous volcanic deposits, the confidence intervals approach $0 \mathrm{Wm}^{-1} \mathrm{~K}^{-1}$ as the boundary condition at $p=100 \%$ is formed 

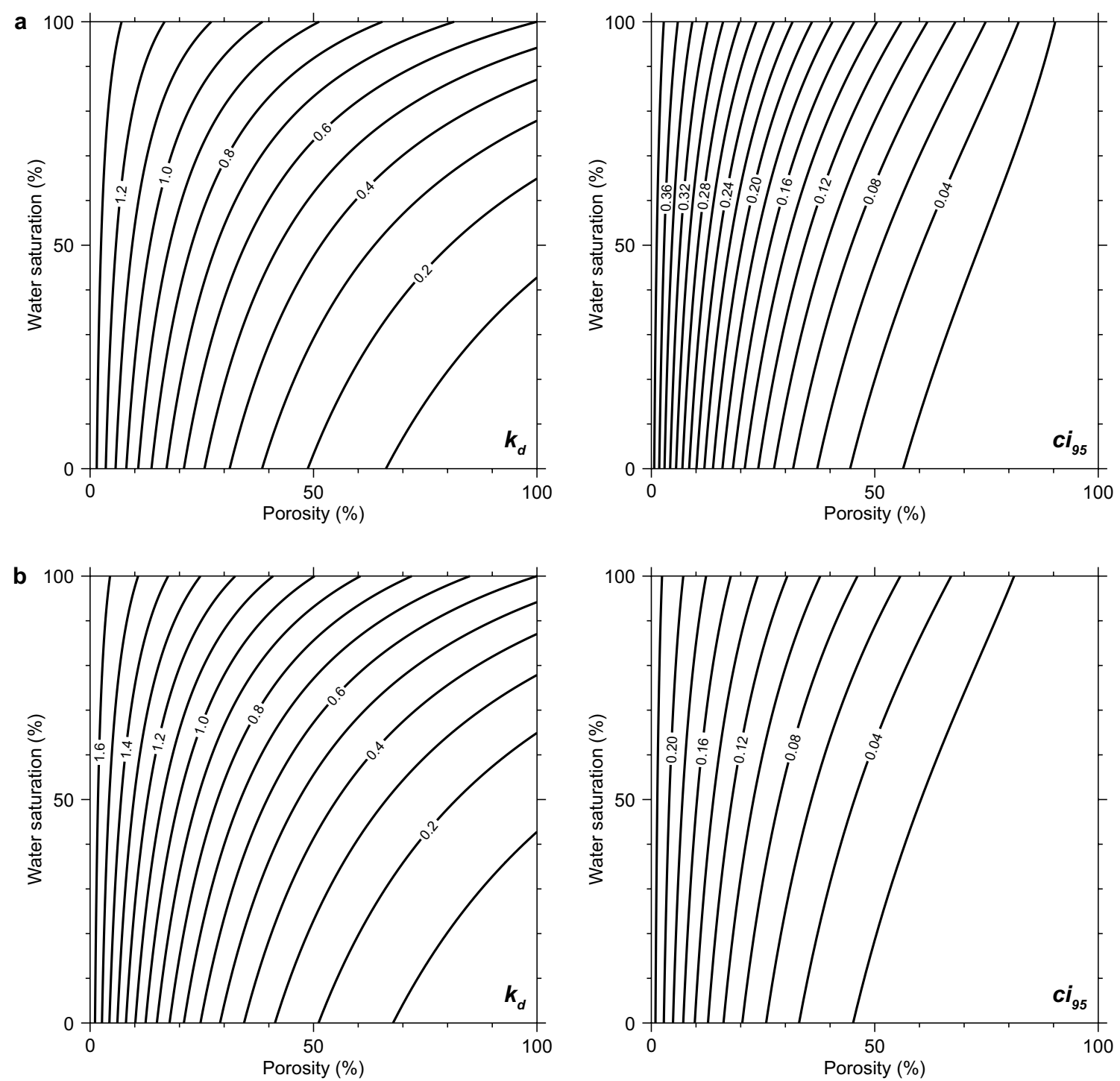

Fig. 8 Ranges of possible bulk thermal conductivities ( $\mathrm{W} \mathrm{m}^{-1} \mathrm{~K}^{-1}$ ) of deposits of EYV10 (a) and GRV11 materials (b) expressed as contour plots over the full range of potential effective porosities and degrees of water saturation of the pore space. Porosity includes both, the effective porosity of the grains of the volcanic material and the pore space between those grains. Grain thermal conductivities of the

exclusively by linear combinations of the physical constants $k_{\mathrm{a}}=0.0262 \mathrm{Wm}^{-1} \mathrm{~K}^{-1}$ and $k_{\mathrm{w}}=0.6 \mathrm{Wm}^{-1} \mathrm{~K}^{-1}$. The confidence intervals reach their maximum extent at $p=0 \%$ where they equal the ones of $k_{\mathrm{g}, \mathrm{C} 2}$.

\section{Discussion}

The results of the laboratory analysis are consistent with theoretical considerations and with the obtained relationships between rock properties and geochemical compositions. The grain density variation across rock types (Fig. 4) volcanic materials are calculated using model $\mathrm{C} 2$. The variation with porosity and water saturation is calculated according to Eq. (8). Left panels show bulk thermal conductivity of the deposit $\left(k_{\mathrm{d}}\right)$ and right panels the continuous variability of the associated $95 \%$ confidence intervals $\left(\mathrm{ci}_{95}\right)$

matches expectations as igneous rocks tend to increase in density with decreasing alkali and silica contents (Hasterok and Webb 2017). Moreover, the measured grain thermal conductivity conclusively mirrors the distribution of the samples across the different rock types, and especially the dominance of basaltic materials. The characteristic thermal conductivity of this rock type $\left(1.69 \mathrm{Wm}^{-1} \mathrm{~K}^{-1}\right.$; Sharma 2002) lies well within the one sigma uncertainty range around the mean grain thermal conductivity of the 43 samples $\left(1.43 \pm 0.38 \mathrm{Wm}^{-1} \mathrm{~K}^{-1}\right)$. However, the variation of grain thermal conductivity across rock types does not unveil any noteworthy correlations with individual major element 
oxides. The main contributor to the alkali contents $\left(\mathrm{Na}_{2} \mathrm{O}\right)$ is the only major element oxide that shows a significant positive correlation both to grain thermal conductivity and to the residuals of the grain density-thermal conductivity relation (Table 3 ). This apparently suggests an increase of grain thermal conductivity with alkali contents, but from a physical-chemical point of view these two properties have to be deemed unrelated as the alkali contents of the 43 samples hardly exceeds $5 \mathrm{wt} \%$ in general. Hence, individual components of the geochemical composition that alone control parts of the variation in grain thermal conductivity cannot be identified. This might also explain the poor performance of model B in estimating grain thermal conductivity and also the rather small increase of performance between models A and $\mathrm{C} 1$ (Fig. 5).

The observed increase of grain thermal conductivity with alkali contents might, nevertheless, be explainable via the relation of $\mathrm{Na}_{2} \mathrm{O}$ to the silica content $\left(\mathrm{SiO}_{2}\right)$. The distribution of the samples in the TAS diagram indicates an increase of silica with alkali content (Fig. 4), and silica-rich, i.e., felsic, rocks tend to contain considerable amounts of quartz, which is a high-conductive mineral $\left(7.69 \mathrm{Wm}^{-1} \mathrm{~K}^{-1}\right.$; Horai 1971).

Overall, the weak correlations between a) geochemical components and grain thermal conductivity and b) geochemical components and residuals of the grain density-thermal conductivity relation (Table 3 ) suggest that important influences of the major element oxides on thermal conductivity might result only from their effect on density. This might also explain that grain density is needed as a predictor in the regression models to reach more than one-third of variance explanation as it is done by the solely geochemistrydependent model B (Fig. 5).

However, grain density may also act as a limiting factor for meaningful comparisons between measured and modeled grain thermal conductivities. The comparison between the measured grain thermal conductivity of sample 8 and the one modeled for the GRV11 material using model C2 revealed considerable differences (Fig. 7), which can be related to inconsistent grain density assumptions. Results suggest the presence of considerable isolated porosity or microporosity in the grains of sample 8, which biases their density towards lower values. Assuming model $\mathrm{C} 2$ to work correctly, this points to an error in the determination of grain thermal conductivity of sample 8 , which is explainable by the fact that the measurement procedure takes no account of any isolated pores in the grains. This means that deviations between modeled and measured grain thermal conductivity do not necessarily indicate a poor model performance. They might also be related to problems with the determination of grain thermal conductivity during the measurement procedure due to a presence of isolated pore space in the grains.

Even the most complete model $\mathrm{C} 1$ is not able to explain more than $59 \%$ of the variance in measured grain thermal conductivity. This suggests the existence of additional controlling factors. The grain thermal conductivity of volcanic materials also depends on the internal structure of the related mineral content. Orientation of the minerals and thus texture of the material, the degree of anisotropy and the potential inhomogeneity of the volcanic material also influence grain thermal conductivity (Krishnaiah et al. 2004; Stephens and Sinnock 1980). Such factors cannot be accounted for in a modeling procedure that aims at estimating thermal conductivity of volcanic materials immediately after a volcanic eruption. For this purpose, model $\mathrm{C} 2$ is the most adequate scheme as it best combines high accuracy with low model uncertainty. It can be run with data of known geochemical compositions of any arbitrary volcanic eruption. The density information can be derived as part of the modeling procedure on the basis of the alkali and silica contents of the erupted volcanic material (Fig. 6). These quantities also qualify for the attribution of a volcanic material to a certain igneous rock type. Therefore, it is even possible to derive approximated density information solely from knowledge of the erupted rock type.

Extending the thermal conductivity modeling from the volcanic grain material to the entire deposit is the most challenging part of the model application. Our procedure covers only the influences of porosity and water saturation. The consideration of porosity includes interconnected, non-isolated pore space within the individual grains of the volcanic material as well as the pore space between them. The former is governed by a direct causal connection to the eruption process, while the latter is determined by grain size distribution and the tightness of the grain packing. The degree of water saturation integrates over the entire pore space, neglecting a potential contribution of adhesive water, which can influence thermal conductivity (Farouki 1981). Also influences of phase changes from liquid to frozen water, which are quite common in supraglacial volcanic deposits are neglected, even though it is known that these may alter thermal conductivity too (Kuznetsova 2017). Since the thermal conductivity of a volcanic deposit is always lower than that of the related volcanic material itself, our modeling approach is, in any case, suitable for deriving the maximum bulk thermal conductivity of such a deposit.

However, as already mentioned, the sample set used in this study shows limitations regarding statistical validity due to the clear dominance of one single rock type, i.e., basalt. From Fig. 3, it can be seen that limiting the sample set to picrobasaltic samples only would induce a distinctly different relation between grain density and grain thermal conductivity and would thus considerably influence the derived regression models. This suggests that from a distinctly larger sample set it would be possible to calibrate the regression models specifically for certain rock types. We expect that such a procedure would yield improved model performance. 


\section{Conclusions}

Samples of volcanic materials from 43 different locations across Iceland have been analyzed with respect to their petrographic characteristics and geochemical compositions. Most of the samples were classified as basaltic. Mean grain thermal conductivity of the 43 samples is $1.43 \pm 0.38 \mathrm{Wm}^{-1} \mathrm{~K}^{-1}$ and mean grain density $2487 \pm 452 \mathrm{~kg} \mathrm{~m}^{-3}$. Grain density was found to be by far the most important single predictor for grain thermal conductivity as indicated by a significant positive correlation of $0.66\left(R^{2}=0.43\right)$. Multiple correlation with all ten major element oxides only reaches $0.58\left(R^{2}=0.33\right)$. Just two out of ten oxides ( $\mathrm{MnO}$ and $\mathrm{Na}_{2} \mathrm{O}$ ) show statistically significant partial correlations to grain thermal conductivity at a rather low level of maximum 0.42 .

Four different regression models for calculation of grain thermal conductivity were set up. They rely on grain density and/or geochemical composition. Models accounting for both (models $\mathrm{C} 1$ and $\mathrm{C} 2$ ) show the highest accuracy with $\mathrm{R}^{2}$ values of up to 0.59 and root mean square errors of no more than $0.28 \mathrm{Wm}^{-1} \mathrm{~K}^{-1}$. However, even these models feature a systematic error. Grain thermal conductivities below $\sim 1.5 \mathrm{Wm}^{-1} \mathrm{~K}^{-1}$ are overestimated, while those above are underestimated. This means that none of the four models covers the full range of measured grain thermal conductivities.

All four models were evaluated regarding their suitability for an application immediately after a volcanic eruption. In this evaluation, a modeling procedure was carried out that determines the possible range of bulk thermal conductivities of a volcanic deposit from known geochemical characteristics of the source volcano only. It was applied to geochemical data of volcanic materials from the Eyjafjallajökull 2010 and the Grímsvötn 2011 volcanic eruptions. Models $\mathrm{C} 1$ and $\mathrm{C} 2$ not only show the highest accuracies but also distinctly lower model uncertainties than model B. The model which best combines high accuracy with low model uncertainty is model C2. It shows a root mean square error of $\pm 0.28 \mathrm{Wm}^{-1} \mathrm{~K}^{-1}$ combined with $95 \%$ confidence intervals of $\pm 0.39 \mathrm{Wm}^{-1} \mathrm{~K}^{-1}$ for the Eyjafjalljökull material or $\pm 0.15 \mathrm{Wm}^{-1} \mathrm{~K}^{-1}$ for the Grímsvötn material. The rather small confidence intervals are a benefit from only four predictor variables. Applying model $\mathrm{C} 2$ yields grain thermal conductivities of the Eyjafjallajökull and Grímsvötn materials of $1.58 \mathrm{Wm}^{-1} \mathrm{~K}^{-1}$ and $1.73 \mathrm{Wm}^{-1} \mathrm{~K}^{-1}$, respectively. In a dry volcanic deposit, these values halve as soon as the porosity of the deposit rises to $\sim 16 \%$. In a completely water-saturated deposit, halving occurs at porosities of $72 \%$ and $65 \%$, respectively.

Results show that our modeling procedure enables the calculation of the maximum bulk thermal conductivity of a volcanic deposit. However, future refinement is needed with respect to the influence of frozen water content, which is an important factor in supraglacial deposits of volcanic materials. Future work might also increase model accuracy by repeating the calibration of the regression models with an extended and more diverse sample set.

Acknowledgements Open Access funding provided by Projekt DEAL. This study was funded by Grants no. KU1476/5-1 and SCHN680/6-1 of the German Research Foundation (DFG). We thank the administration of the Vatnajökull National Park for granting permission for tephra sampling at Grímsvötn caldera and other sites within the national park area. Marianne Dohms is acknowledged for carrying out XRF measurements and an anonymous reviewer for significant improvement of the manuscript.

Open Access This article is licensed under a Creative Commons Attribution 4.0 International License, which permits use, sharing, adaptation, distribution and reproduction in any medium or format, as long as you give appropriate credit to the original author(s) and the source, provide a link to the Creative Commons licence, and indicate if changes were made. The images or other third party material in this article are included in the article's Creative Commons licence, unless indicated otherwise in a credit line to the material. If material is not included in the article's Creative Commons licence and your intended use is not permitted by statutory regulation or exceeds the permitted use, you will need to obtain permission directly from the copyright holder. To view a copy of this licence, visit http://creativecommons.org/licenses/by/4.0/.

\section{References}

Arnalds O, Thorarinsdottir EF, Thorsson J, Dagsson-Waldhauserova P, Agustsdottir AM (2013) An extreme wind erosion event of the fresh Eyjafjallajökull 2010 volcanic ash. Sci Rep 3:1257. https:// doi.org/10.1038/srep01257

Arnalds O, Dagsson-Waldhauserova P, Haraldur O (2016) The Icelandic volcanic aeolian environment: processes and impacts-a review. Aeolian Res 20:176-195. https://doi.org/10.1016/j.aeoli a.2016.01.004

Björnsson H, Pálsson F (2008) Icelandic glaciers. Jökull 58:365-386

Borisova AY, Toutain J-P, Stefansson A, Gouy S, de Parseval P (2012) Processes controlling the 2010 Eyjafjallajökull explosive eruption. J Geophys Res 117:B05202. https://doi.org/10.1029/2012J B009213

Brown RJ, Bonadonna C, Durant AJ (2012) A review of volcanic ash aggregation. Phys Chem Earth 45(46):65-78. https://doi. org/10.1016/j.pce.2011.11.001

Clauser C, Huenges E (1995) Thermal conductivity of rocks and minerals. In: Ahrens TJ (ed) Rock physics and phase relations: a handbook of physical constants. American Geophysical Union, New York, pp 105-126

Corson PB (1974) Correlation functions for predicting properties of heterogeneous materials. IV. Effective thermal conductivity of two-phase solids. J Appl Phys 45:3180. https://doi. org/10.1063/1.1663744

Dagsson-Waldhauserova P, Arnalds O, Ólafsson H (2014) Long-term variability of dust events in Iceland (1949-2011). Atmos Chem Phys 14:13411-13422. https://doi.org/10.5194/acp-14-13411 $-2014$

Dragosics M, Meinander O, Jónsdóttir T, Dürig T, De Leeuw G, Pálsson F, Dagsson-Waldhauserová P, Thorsteinsson T (2016) 
Insulation effects of Icelandic dust and volcanic ash on snow and ice. Arab J Geosci 9:126. https://doi.org/10.1007/s1251 7-015-2224-6

Farouki OT (1981) The thermal properties of soils in cold regions. Cold Reg Sci Tech 5:67-75. https://doi.org/10.1016/0165232X(81)90041-0

García A, Contreras E, Viggiano JC (1989) Establishment of an empirical correlation for estimating the thermal conductivity of igneous rocks. Int J Thermophys 10:1063-1074. https://doi.org/10.1007/ BF00503174

Gudmundsdóttir ER, Larsen G, Björck S, Ingólfsson Ó, Striberger J (2016) A new high-resolution Holocene tephra stratigraphy in eastern Iceland: improving the Icelandic and North Atlantic tephrochronology. Quat Sci Rev 150:234-249. https://doi. org/10.1016/j.quascirev.2016.08.011

Gudmundsson A (1995) Ocean-ridge discontinuities in Iceland. J Geol Soc 152:1011-1015. https://doi.org/10.1144/GSL. JGS.1995.152.01.22

Gudmundsson MT, Thordarson T, Höskuldsson Á, Larsen G, Björnsson H, Prata FJ, Oddsson B, Magnússon E, Högnadóttir T, Petersen GN, Hayward CL, Stevenson JA, Jónsdóttir I (2012) Ash generation and distribution from the April-May 2010 eruption of Eyjafjallajökull, Iceland. Sci Rep 2:572. https ://doi.org/10.1038/srep00572

Gudnason J, Thordarson T, Houghton BF, Larsen G (2017) The opening subplinian phase of the Hekla 1991 eruption: properties of the tephra fall deposit. Bull Volcanol 79:34. https://doi. org/10.1007/s00445-017-1118-8

Hasterok D, Webb J (2017) On the radiogenic heat production of igneous rocks. Geosci Front 8:919-940. https://doi. org/10.1016/j.gsf.2017.03.006

Horai K (1971) Thermal conductivity of rock-forming minerals. J Geophys Res 76:1278-1308. https://doi.org/10.1029/JB076 i005p01278

Horai K, Baldridge S (1972) Thermal conductivity of nineteen igneous rocks, II estimation of the thermal conductivity of rock from the mineral and chemical compositions. Phys Earth Planet Inter 5:157-166. https://doi.org/10.1016/0031-9201(72)90085-4

Jakobsson SP (1979) Outline of the petrology of Iceland. Jökull 29:57-73

Jakobsson SP, Gudmundsson MT (2008) Subglacial and intraglacial volcanic formations in Iceland. Jökull 58:179-196

Jakobsson SP, Jónasson K, Sigurdsson IA (2008) The three igneous rock series of Iceland. Jökull 58:117-138

Jenkins R (1999) X-ray fluorescence spectrometry. Wiley, New York Jóhannesson H, Sæmundsson K (2009) Geological map of Iceland, 1:600:000, tectonics. Icelandic Institute of National History, Reykjavik

Jude-Eton TC, Thordarson T, Gudmundsson MT, Oddsson B (2012) Dynamics, stratigraphy and proximal dispersal of supraglacial tephra during the ice-confined 2004 eruption at Grímsvötn volcano, Iceland. Bull Volcanol 74:1057-1082. https://doi. org/10.1007/s00445-012-0583-3

Kellerer-Pirklbauer A, Farbrot H, Etzelmüller B (2007) Permafrost aggradation caused by tephra accumulation over snowcovered surfaces: examples from the Hekla-2000 eruption in Iceland. Permafrost Periglac Process 18:269-284. https://doi. org/10.1002/ppp.596

Kirkbride MP, Dugmore AJ (2003) Glaciological response to distal tephra fallout from the 1947 eruption of Hekla, south Iceland. J Glaciol 49:420-428. https://doi.org/10.3189/172756503781830 575

Krishnaiah S, Singh DN, Jadhav GN (2004) A methodology for determining thermal properties of rocks. Int J Rock Mech Min Sci 41:877-882. https://doi.org/10.1016/j.ijrmms.2004.02.004
Kuznetsova E (2017) Thermal conductivity and the unfrozen water content of volcanic ash deposits in cold climate conditions: a review. Clays Clay Miner 65:167-182. https://doi.org/10.1346/ CCMN.2017.064057

Larsen G, Eiríksson J (2007) Late quaternary terrestrial tephrochronology of Iceland - frequency of explosive eruptions, type and volume of tephra deposits. J Quatern Sci 23:109-120. https:// doi.org/10.1002/jqs.1129

Larsen G, Gudmundsson MT, Björnsson H (1998) Eight centuries of periodic volcanism at the center of the Iceland hotspot revealed by glacier tephrostratigraphy. Geology 26:943-946. https://doi.org/10.1130/0091-7613(1998)026\%3C0943:ECOPV A\%3E2.3.CO;2

Le Bas MJ, Le Maitre RW, Streckeisen A, Zanettin B (1986) A chemical classification of volcanic rocks based on the total alkalisilica diagram. J Petrol 27:745-750. https://doi.org/10.1093/ petrology/27.3.745

Liu EJ, Cashman KV, Beckett FM, Witham CS, Leadbetter SJ, Hort MC, Guðmundsson S (2014) Ash mists and brown snow: remobilization of volcanic ash from recent Icelandic eruptions. J Geophys Res Atmos 119:9463-9480. https://doi.org/10.1002/2014J D021598

Machida H (2002) Impact of tephra forming eruptions on human beings and the environment. Glob Environ Res 6:61-68

Möller R, Möller M, Björnsson H, Gudmundsson S, Pálsson F, Oddsson B, Kukla PA, Schneider C (2014) MODIS-derived albedo changes of Vatnajökull (Iceland) due to tephra deposition from the 2004 Grimsvötn eruption. Int J Appl Earth Obs Geoinf 26:256269. https://doi.org/10.1016/j.jag.2013.08.005

Möller R, Möller M, Kukla PA, Schneider C (2016) Impact of supraglacial deposits of tephra from Grimsvötn volcano, Iceland, on glacier ablation. J Glaciol 62:933-943. https://doi.org/10.1017/ jog. 2016.82

Möller R, Möller M, Kukla PA, Schneider C (2018) Modulation of glacier ablation by tephra coverage from Eyjafjallajökull and Grímsvötn volcanoes, Iceland: an automated field experiment. Earth Syst Sci Data 10:53-60. https://doi.org/10.5194/ essd-10-53-2018

Möller R, Dagsson-Waldhauserová P, Möller M, Kukla PA, Schneider C, Gudmundsson MT (2019) Persistent albedo reduction on southern Icelandic glaciers due to ashfall from the 2010 Eyjafjallajökull eruption. Remote Sens Environ 233:111396. https://doi. org/10.1016/j.rse.2019.111396

Neave DA, Maclennan J, Thordarson T, Hartley ME (2015) The evolution and storage of primitive melts in the Eastern Volcanic Zone of Iceland: the 10ka Grímsvötn tephra series (i.e. the Saksunarvatn ash). Contrib Mineral Petrol 170:21. https://doi.org/10.1007/ s00410-015-1170-3

Nicholson L, Benn DI (2013) Properties of natural supraglacial debris in relation to modelling sub-debris ice ablation. Earth Surf Proc Land 38:490-501. https://doi.org/10.1002/esp.3299

Óladóttir BA, Sigmarsson O, Larsen G, Thordarson T (2008) Katla volcano, Iceland: magma composition, dynamics and eruption frequency as recorded by Holocene tephra layers. Bull Volcanol 70:475-493. https://doi.org/10.1007/s00445-007-0150-5

Óladóttir BA, Larsen G, Sigmarsson O (2011) Holocene volcanic activity at Grímsvötn, Bárdarbunga and Kverkfjöll subglacial centres beneath Vatnajökull, Iceland. Bull Volcanol 73:1187-1208. https ://doi.org/10.1007/s00445-011-0461-4

Olsson J, Stipp SLS, Dalby KN, Gislason SR (2013) Rapid release of metal salts and nutrients from the 2011 Grímsvötn, Iceland volcanic ash. Geochim Cosmochim Acta 123:134-149. https:// doi.org/10.1016/j.gca.2013.09.009

Sæmundsson K (1979) Outline of the geology of Iceland. Jökull 29:7-28 
Sharma PV (2002) Environmental and engineering geophysics. Cambridge University Press, Cambridge

Sigmarsson O, Steinthórsson S (2007) Origin of Icelandic basalts: a review of their petrology and geochemistry. J Geodyn 43:87-100. https://doi.org/10.1016/j.jog.2006.09.016

Stephens HP, Sinnock S (1980) Thermophysical properties of rocks: a perspective on data needs, sources and accuracy. In: Sengers JV, Klein M (eds) The technological importance of accurate thermophysical property information, NBS Special Publication 590. US Department of Commerce, Washington, pp 27-32

Stevenson JA, Loughlin SC, Font A, Fuller GW, MacLeod A, Oliver IW, Jackson B, Horwell CJ, Thordarson T, Dawson I (2013) UK monitoring and deposition of tephra from the May 2011 eruption of Grímsvötn, Iceland. J Appl Volcan 2:3. https://doi. org/10.1186/2191-5040-2-3
Thordarson T, Höskuldsson Á (2008) Postglacial volcanism in Iceland. Jökull 58:197-228

Thordarson T, Larsen G (2007) Volcanism in Iceland in historical times: volcano types, eruption styles and eruptive history. J Geodyn 43:118-152. https://doi.org/10.1016/j.jog.2006.09.005

Von Herzen R, Maxwell AE (1959) The measurement of thermal conductivity of deep-sea sediments by a needle-probe method. J Geophys Res 64:1557-1563. https://doi.org/10.1029/JZ064i010p 01557

Wittmann M, Groot Zwaaftink CD, Steffensen Schmidt L, Guðmundsson S, Pálsson F, Arnalds O, Björnsson H, Thorsteinsson T, Stohl A (2017) Impact of dust deposition on the albedo of Vatnajökull ice cap, Iceland. Cryosphere 11:741-754. https://doi.org/10.5194/ tc-11-741-2017 